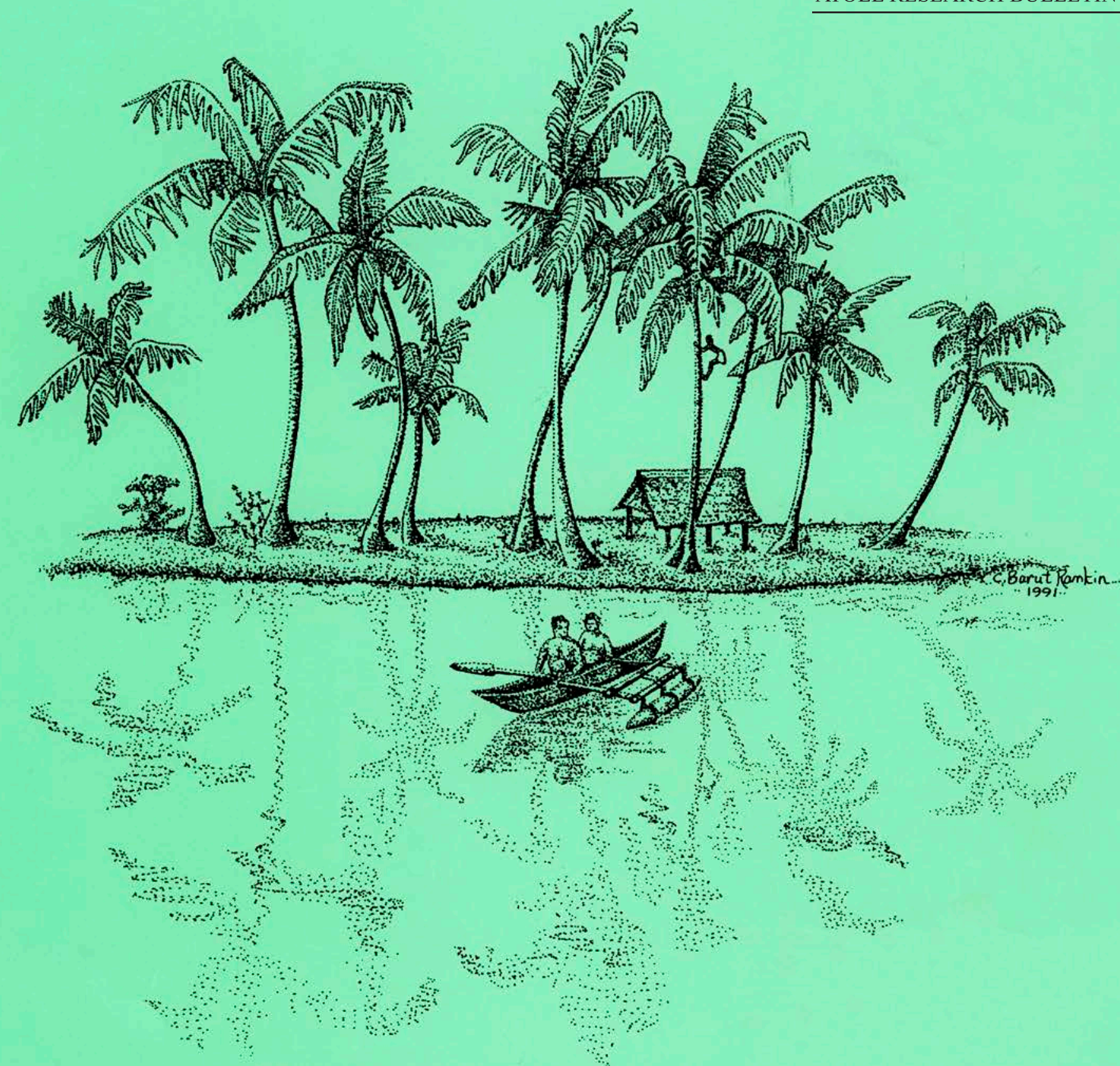

FRINGING REEFS OF REUNION ISLAND

AND EUTROPHICATION EFFECTS

No. 596

PART 1: Long-Term Monitoring of Two Shallow Coral Reef Communities Catherine Tourrand, Odile Naim, Lionel Bigot, Christophe Cadet, Bruce Cauvin,

Stuart Semple, Lucien F. Montaggioni, Pascale Chabanet and Henrich Bruggemann

No. 597

PART 2: Long-Term Monitoring of Primary Producers

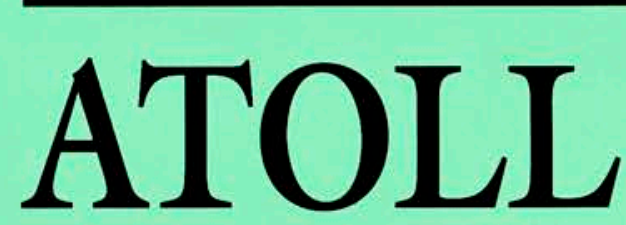

Odile Naim, Catherine Tourrand, Enric Ballesteros, Stuart Semple, Lionel Bigot,

Bruce Cauvin, Pascale Cuet, and Lucien F. Montaggioni

No. 598

PART 3: Long-Term Monitoring of Living Corals

Odile Naim, Catherine Tourrand, Gerard F. Faure, Lionel Bigot, Bruce Cauvin,

Stuart Semple and Lucien F. Montaggioni

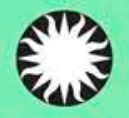

Smithsonian Institution Scholarly Press
RESEARCH

BULLETIN 


\section{FRINGING REEFS OF REUNION ISLAND AND EUTROPHICATION EFFECTS}

PART 1: Long-Term Monitoring of Two Shallow Coral Reef Communities

Catherine Tourrand, Odile Naim, Lionel Bigot, Christophe Cadet, Bruce Cauvin, Stuart Semple, Lucien F. Montaggioni, Pascale Chabanet and Henrich Bruggemann

PART 2: Long-Term Monitoring of Primary Producers

Odile Naim, Catherine Tourrand, Enric Ballesteros, Stuart Semple, Lionel Bigot, Bruce Cauvin, Pascale Cuet, and Lucien F. Montaggioni

PART 3: Long-Term Monitoring of Living Corals

Odile Naim, Catherine Tourrand, Gerard F. Faure, Lionel Bigot, Bruce Cauvin, Stuart Semple and Lucien F. Montaggion

Atoll Research Bulletin No. 597 15 November 2013

Snithsonian Institution

Scholarly Press 
All statements made in papers published in the Atoll Research Bulletin are the sole responsibility of the authors and do not necessarily represent the views of the Smithsonian Institution or of the editors of the Bulletin. Articles submitted for publication in the Atoll Research Bulletin should be original papers and must be made available by authors for open access publication. Manuscripts should be consistent with the "Author Formatting Guidelines for Publication in the Atoll Research Bulletin." All submissions to the Bulletin are peer reviewed and, after revision, are evaluated prior to acceptance and publication through the publisher's open access portal, Open SI (http://opensi.si.edu).

Published by SMITHSONIAN INSTITUTION SCHOLARLY PRESS

P.O. Box 37012, MRC 957

Washington, D.C. 20013-7012

www.scholarlypress.si.edu

The rights to all text and images in this publication are owned either by the contributing authors or third parties. Fair use of materials is permitted for personal, educational, or noncommercial purposes. Users must cite author and source of content, must not alter or modify the content, and must comply with all other terms or restrictions that may be applicable. Users are responsible for securing permission from a rights holder for any other use.

ISSN: 0077-5630 (online) 


\title{
FRINGING REEFS OF REUNION ISLAND AND EUTROPHICATION EFFECTS. PART 2: LONG-TERM MONITORING OF PRIMARY PRODUCERS
}

\author{
BY
}

\begin{abstract}
ODILE NAIM, ${ }^{1,2 *}$ CATHERINE TOURRAND, ${ }^{3,2}$ ENRIC BALLESTEROS ${ }^{4}$, STUART SEMPLE, ${ }^{5}$ LIONEL BIGOT, ${ }^{2}$ BRUCE CAUVIN,${ }^{6}$ PASCALE CUET, ${ }^{2}$ and LUCIEN F. MONTAGGIONI $^{7}$
\end{abstract}

\begin{abstract}
Studies on the reef flat of Saint-Gilles La Saline between 1987 and 2009 compared spatio-temporal variations of primary producers on two sites, Toboggan and Planch'Alizés. Toboggan (Site-T) is an oligotrophic site characterized by Acropora corals, abundant sea urchins and few primary producers. Planch'Alizés (Site-P) is a heterotrophic site, characterized by massive corals, abundant primary producers and occasional sea urchins. From shore to outer reef front, the reef flat comprises three parts: the back reef (B), the coral zone with Large coral strips (L) and the coral zone with Narrow coral strips $(\mathrm{N})$.

This paper (which is Part 2 in a three part series) is divided into four sections. The first (1993, 1996, and 2002) focuses on four groups of primary producers: cyanophytes; turfs (including Stegastes epilithic algal communities); encrusting coralline algae; macroalgae. Their abundance and dominant species were recorded in the three subzones, B, L and N, using 50m-line intercept transects (LITs). The second section (1998 to 2009 inclusive, on the two same sites), reports on annually monitored turfs, encrusting coralline and macroalgae on two permanent $20 \mathrm{~m}$ LITs. These annual records extend periodic records from these same LITs from 1987, 1993, 1996 and 2002. The third section describes species richness of primary producers at the infracentimetric level in zones B, L and N in 1994. In the final section, seasonal variability is documented as changes in the biomass of dominant macroalgae reported monthly over a period of seven months (1993-94).
\end{abstract}

In 1993-2002, primary producers were dominant at $\mathrm{P}$ (average $\sim 60 \%$ ) but inconspicuous at $\mathrm{T}(\sim 5 \%)$. In terms of relative cover, turfs and macroalgae were the dominant forms at both sites $(75 \%$ turfs, $10 \%$ macroalgae at $\mathrm{T} ; 24 \% \mathrm{t}$. and $52 \% \mathrm{~m}$. at P). On both sites, cyanophytes significantly decreased over time. Among turfs, fine filamentous turfs were prevalent on the back reef on both sites, and also on the

\footnotetext{
1 Laboratoire GMGL, Université de Bretagne Sud, Vannes, France

2 Laboratoire ECOMAR, Université de la Réunion, Saint-Denis, France (DOM)

3 Département de Physique, Université de la Réunion, Saint-Denis, France (DOM)

4 CEAB, CSIC, Blanes, Spain

5 Department of Life Sciences, Roehampton University, England

6 GIP Réserve Nationale Marine de la Réunion, France (DOM)

7 UMR 6536, Université d'Aix-Marseille, France

* Email : odile.naim@univ-reunion.fr
} 
narrow outer coral zone at P. Stegastes turf territories dominated both coral zones at Site-T (L and N), but only the L coral zone at Site-P. Encrusting coralline algae were sparse at Site-T but locally abundant at Site-P, where they increased significantly from 1993 to 1996 in both coral zones. There was a major decrease in macroalgae between 1993 and 2002 at P. There were marked differences in the trajectories of decline of the dominant soft macroalgae (Hypnea valentiae, Padina spp, Dictyota spp, Turbinaria ornata and Gracilaria canaliculata).

Seventy six primary producer species were recorded in the infracentimetric study (52 species at $\mathrm{T}$ and 67 at $\mathrm{P}$ ). Different algae dominated different areas at both sites. At Toboggan, locally dominant species were the small Gelidium pusillum, an unidentified Melobesiae, Jania adhaerens, the encrusting corallines Hydrolithon onkondes and Lobophora variegata, the turfs Polysiphonia mollis and Anotrichium tenue (mainly in Stegastes territories), Jania adhaerens and Dictyosphaeria verluysii. At $\mathrm{P}$, the dominants were Mesophyllum erubescens encrusting dead hard substrates and decimetric bioclasts in the back reef (B), where they form numerous rhodoliths. In the P coral zones, the dominant taxa were Lyngbya majuscula (cyanobacteria) followed by Hydrolithon onkodes, Blennothrix cantharidosma and Lithophyllum kotschyanum. Jania adhaerens, Hydrolithon onkodes and Gelidiella acerosa were dominant in the narrow coral zone $(\mathrm{N})$. The local composition of the algal community appears to be more related to geomorphological zones and the presence or absence of the territorial Stegastes fish than to environmental differences between T and P.

There was strong seasonal change in macroalgae biomass in 1993-4. On the back reef of both sites, peak biomass was due to Hypnea valentiae in February, when it is significantly greater than it was in January. Dictyosphaeria verluysii was dominant and highly visible at Site-T, but extremely rare and hidden below the Hypnea valentiae at $\mathrm{P}$. On the outer coral zone $(\mathrm{N})$, biomass was significantly different between most months on both sites. At Site-T in summer (December to March) the peak biomass was due to the "sponge seaweed" Hydroclathrus clathratus (Phaeophyceae) which exploded in December, declined in January and disappeared in February. At Site-P, H.clathratus was almost absent, and instead, Gracilaria canaliculata dominated the community throughout the year. Dictyosphaearia verluysii and $D$. cavernosa were prevalent in winter, the former preferring intertidal locations. In autumn (April - June), Turbinaria ornata invaded the subtidal substrates on the outer $\mathrm{N}$-zones.

To conclude this Part 2 of the Reunion Island Fringing Reef series, we discuss the influence of nutrients and herbivores (especially sea urchins and the territorial damselfish Stegastes) on the abundance and distribution of primary producers.

Key words: Coral reefs, benthic community, subtidal, stability, algae, coverage, diversity, biomass, cyanophytes, turf algae, encrusting corallines, macroalgae, Lyngbya majuscula, Gracilaria canaliculata, Hypnea valentiae, sea urchins, nutrients, herbivory.

\section{INTRODUCTION}

Tropical seas generally host a huge biodiversity, and on coral reefs, the variety of sizes, shapes and colors of algae is remarkable as is the versatility of their occurrence and their species richness (Tsuda, 1974; Benayahu \& Loya, 1977; Payri \& Naim, 1982; Berner, 1990; Littler et al., 2009). Marine algae comprise one-third of all 
phyla of the plant kingdom, and have been evolving longer than any group of organisms on earth. In association with stony corals, algae are also the major primary producers and builders of coral reefs. Nevertheless, ecological studies are greatly hindered by the complexity of marine algae taxonomy, especially when trying to understand the effects of anthropogenic and natural changes on the future of marine plant life.

In order to better understand the critical role played by algae in reef ecosystems, the benthic algal community that inhabits the two selected sites ("Toboggan", Site-T; and "Planch'Alizés", Site-P) was monitored on the Saint-Gilles La Saline fringing reef (western coast of Reunion Island). These sites are typified by a significant difference in algal abundance. On the two sites, the present work aims to assess: (1) the temporal variation of the two community structures of primary producers during the 1993-2003 time period, (2) the evolution of major groups of primary producers from 1987 to 2009 on two permanent transects, (3) the algal species richness and (4) the biomass variability of the dominant macroalgae in a eight-month interval.

\section{MATERIAL AND METHODS}

The general environmental setting of the Saint-Gilles La Saline reef flat and the details of methods, location of transects etc. were previously described in details in Tourrand et al. (2013). At "Toboggan" and "Planch'Alizés" sites, the inner parts of the fringing reef extend over $330 \mathrm{~m}$ from the shoreline seawards. Three morphological zones were identified successively across each reef profile. The backreef zone (labelled B, TB at Site-T and PB at Site-P), 1.5m deep, extends to a distance of $130 \mathrm{~m}$ seawards from the shoreline. The coral zone is divided into two subzones: a deeper one $(0.8 \mathrm{~m})$, with large coral strips (labelled L, TL at Site-T and PL at Site-P), extending between the 130 and $280-\mathrm{m}$ boundary marks along the profiles, and a shallower one $(0.4 \mathrm{~m})$ with narrow coral strips (labelled N, TN at Site-T and PN at Site-P), extending from the 280 to $330-\mathrm{m}$ boundary marks. Four complementary datasets were gained.

Survey 1: Coverage by dominant primary producers at the $\geq 1 \mathrm{~cm}$ level from 1993 to 2002.

This survey was done using the line intercept transect (LIT) method, thus only $\geq 1 \mathrm{~cm}$ mats have been recorded (Table 1).

In this study, the primary producers were divided into 4 major groups: (a) the Cyanophytes, (b) the turf algae, (c) the encrusting corallines, and (d) the macroalgae. Marine phanerogams, abundant in the north of Saint-Gilles, were limited to a few patches of Syringodium isoetifolium, one to several meters in diameter, in the coral zone at Site-P, and were not recorded on the LITs.

Cyanobacteria. They generally occurred as episodic blooms on the SaintGilles La Saline reef. As a result, they were generally underestimated by the LIT method.

Turf algae. They are subdivided into 3 groups: (1) the very fine filamentous turfs (AG) including very small species (i.e. Jania adhaerens); this assemblage was not determined at the species level therein; (2) the territorial damselfish Stegastes turfs (AGS). Composed of a mixture of species protected by the damselfish (Lison de 
Loma \& Ballesteros, 2002), these turfs were classified all together as "Stegastes turfs", (3) the outer reef turfs (AGE). They occurred as c.10 cm-high cushions, and were composed of an assemblage of small corallines and fleshy algae (see the "Results" Section).

Table 1: Summary of the 4 survey methods. "LIT"= Line Intercept Transect. "T180" means : a permanent transect, marked off every 5 meters at Site-T, distance from the shore line : $180 \mathrm{~m}$. B: Back reef, L: zone of large and deep coral strips, N: zone of narrow and shallow coral strips.

\begin{tabular}{|c|c|c|c|c|}
\hline & Aim of the study & Stations & Method & Period \\
\hline Survey 1 & $\begin{array}{l}\text { Estimation of coverage } \\
\text { and species } \\
\text { composition of major } \\
\text { fixed benthic categories }\end{array}$ & $\begin{array}{l}\text { At each site, } \mathrm{T} \text { and } \mathrm{P} \text {, } \\
\text { LITs are parallel to the } \\
\text { front, run at fixed } \\
\text { intervals of } 30 \mathrm{~m} \text {, from } \\
30 \mathrm{~m} \text { to } 330 \mathrm{~m} \text { off the } \\
\text { beach }\end{array}$ & $\begin{array}{c}50 \mathrm{~m}-\mathrm{LIT} \\
\text { data separated in } 10 \mathrm{~m} \\
\text { samples }\end{array}$ & $\begin{array}{l}\text { 1993, 1996, 2002, hot } \\
\text { season }\end{array}$ \\
\hline Survey 2 & $\begin{array}{l}\text { Estimation of coverage } \\
\text { and species } \\
\text { composition of major } \\
\text { fixed benthic categories }\end{array}$ & $\begin{array}{c}\text { LITs: T 180, P } 270 \\
\text { (L-zone) }\end{array}$ & $\begin{array}{l}\text { Permanent transects } \\
\qquad(2 * 20 \mathrm{~m})\end{array}$ & $\begin{array}{l}\text { 1987, } 1993,1996, \\
\text { 2002, and each year } \\
\text { from } 1998 \text { to } 2009, \text { hot } \\
\text { season }\end{array}$ \\
\hline Survey 3 & Biodiversity of algae & $\begin{array}{l}\text { Permanent LITs : } \\
\text { T070, P070 (B-zone), } \\
\text { T180, P270 (L-zone), } \\
\text { T240, P330 (N-zone) }\end{array}$ & $\begin{array}{c}\text { Occurrence of all } \\
\text { species of algae into } 40 \\
\{25 * 25 \mathrm{~cm}\} \text { quadrats } \\
\text { (with } 25 \text { materialized } \\
\text { subquadrats }\{5 * 5 \mathrm{~cm}\} \\
\text { into each quadrat) } \\
\text { along permanent } 50 \mathrm{~m} \\
\text { LIT }\end{array}$ & February 1994 \\
\hline Survey 4 & $\begin{array}{l}\text { Temporal variation of } \\
\text { algal biomass }\end{array}$ & $\begin{array}{c}\text { Permanent LITs : } \\
\text { T070, P070 (B-zone) } \\
\text { T240, P330 (N-zone) }\end{array}$ & $\begin{array}{c}\text { Sampling of } \\
\text { macroalgae into } \\
30\{25 * 25 \mathrm{~cm}\} \\
\text { quadrats along } \\
\text { permanent 50m-LIT }\end{array}$ & $\begin{array}{c}\text { Each month } \\
\text { (Dec.1993 to June } \\
1994)\end{array}$ \\
\hline
\end{tabular}

Encrusting corallines. On the Saint-Gilles La Saline reef flat, they cover dead coral skeletons, some of them forming rising knobs or pillars. They also cover bioclasts, forming rhodoliths in some back-reefs. They are recorded without taxonomic details in datasets 1 and 2.

Macroalgae. When possible, they are identified at the species level or recorded as "mixed macroalgae" when too intimately mixed together. Epiphytes occurring on macroalgae were not taken into account in this survey.

Survey 2: coverage of primary producers from 1987 to 2009 , at the $\geq 1 \mathrm{~cm}$ level along two permanent transects

Two permanent transects were established in 1987 in the coral zone (L-zone) at both sites, and monitored in 1987, 1993, 1996, 2002, and also from 1998 by the Global Coral Reef Monitoring Network (GCRMN). Three categories of primary producers are taken into account in the GCRMN: turf algae, encusting corallines, and macroalgae. 
Survey 3: estimation of the species richness at a fine resolution along 3 permanent transects (back reef, $\mathrm{L}$ and N-zones)

The species richness of primary producers was estimated in February 1994 along three permanent transects $(50 \mathrm{~m})$ settled in back reef, $\mathrm{L}$ and $\mathrm{N}$-zones respectively (Table 1). Forty quadrats of $25 * 25 \mathrm{~cm}$, divided into 25 sub-quadrats of $5 * 5 \mathrm{~cm}$, were thrown at random along the $50 \mathrm{~m}$ line and the occurrence of all the species of algae (including epiphytes) into the 1000 subquadrats were recorded (infracentimetric resolution); additional sampling was made when further laboratory analysis was needed.

Survey 4: study of macroalgae biomass on 2 permanent transects (Back reef, N-zone)

Variations in macroalgal coverage and simultaneous biomass (wet and dry weight) were recorded from December 1993 to June 1994 at 2 stations from back-reef and $\mathrm{N}$-coral zones (Table 1). A quadrat of $25 * 25 \mathrm{~cm}$, was thrown at random along a $50 \mathrm{~m}$ line transect. After measuring the coverage of dominant macroalgae present into the quadrat, their thalli were removed from the substrate and, in the laboratory, preserved in 5\% formaldehyde sea water. A calcareous stone was added to produce a neutral $\mathrm{pH}$, in order to preserve the integrity of the samples. Later, samples were rinsed under running freshwater (to remove particulate matter and associated microorganisms), sorted at the species level and identified. Wet weight of each species was measured after removing excess water by spinning, and dry weight immediately after drying for $24 \mathrm{~h}$ at $100^{\circ} \mathrm{C}$.

\section{Data analysis}

Due to the multi-species nature of the data and the design of the survey, the most appropriate analyses were multivariate (Clarke \& Warwick 2001). To assess patterns in benthic data from all stations in all years, we used non-metric multidimensional scaling (MDS) and principal component analysis (PCA), and to assess temporal patterns in benthic variation, we used Kruskal-Wallis one-way analysis of variance by ranks: this non-parametric method tests equality of population medians among groups. It is identical to a one-way analysis of variance with the data replaced by their ranks and is an extension of the Mann-Whitney $U$ test to 3 or more groups.

\section{Means and standard deviation}

Mean coral coverage and densities are given with standard deviation, SD (mean $\pm \mathrm{SD}$ ). These are calculated as per the following example (shown only for mean calculation here): on Site-T, for a given parameter (e.g. the primary producer coverage), the mean in a subzone (e.g. the back reef, B), for a given-year (e.g. 1993) is denoted TB93, and is the average over the 20 " $10 \mathrm{~m}$-samples" taken on TB (which means the average of the $50 \mathrm{~m}$-LITs located at $30 \mathrm{~m}, 60 \mathrm{~m}, 90 \mathrm{~m}$ and $120 \mathrm{~m}$ ). Similarly, the TL93 mean is the average over the 25 "10m-samples" taken on TL in 1993 (150 to $270 \mathrm{~m}$ LITs), and the TN93 is the average over the 10 "10m samples" taken on TN in 1993 (300 and 330m LITs). The TB mean is the average over the 60 " $10 \mathrm{~m}$ samples" taken in the back reef (20 in each of 1993, 1996 and 2002); the T mean is the average over the 165 "10m-samples" taken (55 in each of 1993, 1996 and 2002). 


\section{RESULTS}

Survey 1: The two sites, T and P, between 1993 and 2002: spatio-temporal variation of the 4 dominant groups (cyanophytes, turf algae, encrusting corallines and macroalgae)

Distribution of the 4 groups of primary producers at both sites. From dataset 1, the primary producers appeared to be largely dominant at Site-P and inconspicuous at Site-T (T: $5.2 \pm 11.4 \%$ of coverage, P: $61.3 \pm 26.6 \%)$. In the MDS treatment, we can see that bubbles of Cyanophytes, turf algae (including small turfs, damselfish turfs and outer reef turfs), encrusting corallines and macroalgae mostly occur on P-LITs (Fig. 1).

Generalities and temporal variation. At both sites, turfs and macroalgae dominated and averaged 75 to $85 \%$ of primary producer coverage (Table 2).

Table 2. Percent coverage and relative percentage of the three dominant groups of primary producers from 1993 to 2002 at the two sites (from 30 to $330 \mathrm{~m}$ ).

\begin{tabular}{|c|c|c|c|c|}
\hline $\begin{array}{c}\text { Survey } 1 \\
(1993-1996-2002)\end{array}$ & $\begin{array}{c}\text { Site-T } \\
(\% \text { coverage })\end{array}$ & $\begin{array}{c}\text { Site-P } \\
(\% \text { coverage })\end{array}$ & $\begin{array}{c}\text { Site-T } \\
(\text { relative \%) }\end{array}$ & $\begin{array}{c}\text { Site-P } \\
(\text { relative \%) }\end{array}$ \\
\hline Cyanophytes & $0.3(1.0)$ & $4.8(7.6)$ & 5.8 & 7.8 \\
\hline Turfs $(A G+A G S+A G E)$ & $3.9(11.0)$ & $14.5(17.5)$ & 75.0 & 23.6 \\
\hline Encrusting coralline & $0.5(2.1)$ & $10.4(13.1)$ & 9.6 & 17.0 \\
\hline Macroalgae & $0.5(2.0)$ & $31.6(29.5)$ & 9.6 & 51.6 \\
\hline TOTAL & $5.2(11.4)$ & $61.3(26.6)$ & $100 \%$ & $100 \%$ \\
\hline
\end{tabular}

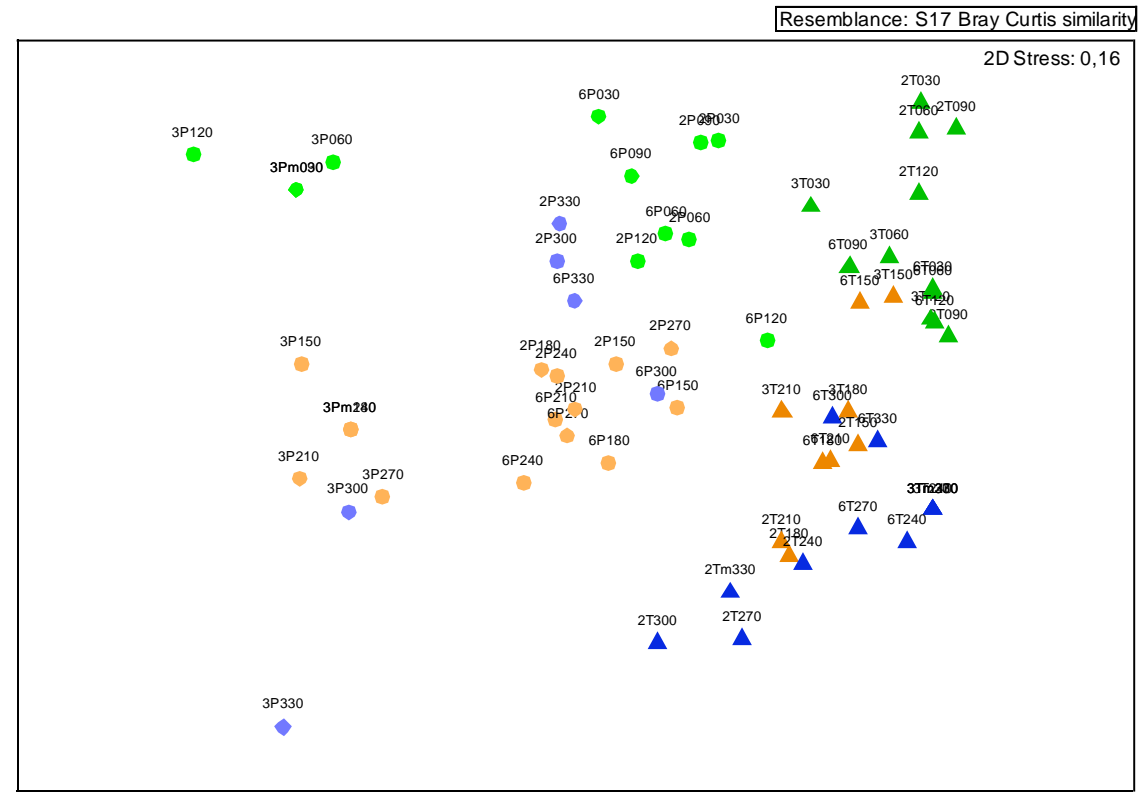

Figure 1a: Two dimensional-MDS configuration obtained with a hierarchical clustering of all the 50m-LIT (all benthic data: corals, algae, etc., echinoderms and territorial fish included, details in Tourrand et al., 2013) using group-average linking of Bray-Curtis. "LIT 3P330" means: year 1993, Site-P, 330 m off the beach; similarly, "LIT 6T60" means: year 1996, Site-T, $60 \mathrm{~m}$ off the beach, 2P50: year 2002 etc. T: triangles, P: circles; Back reef in green, Lzone in orange and N-zone in blue. 
1b. Cyanophytes

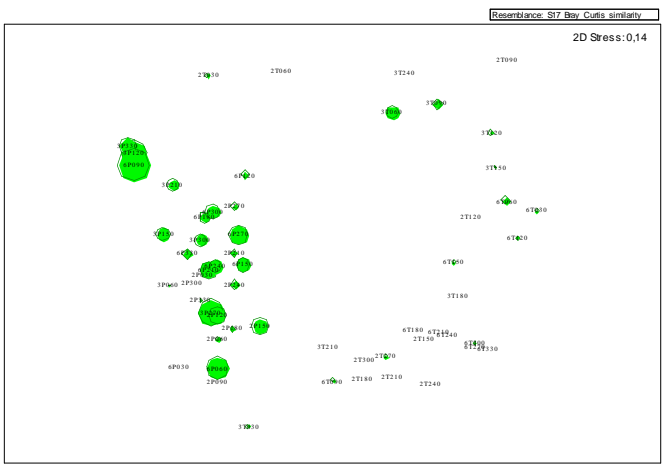

1d. Encrusting corallines

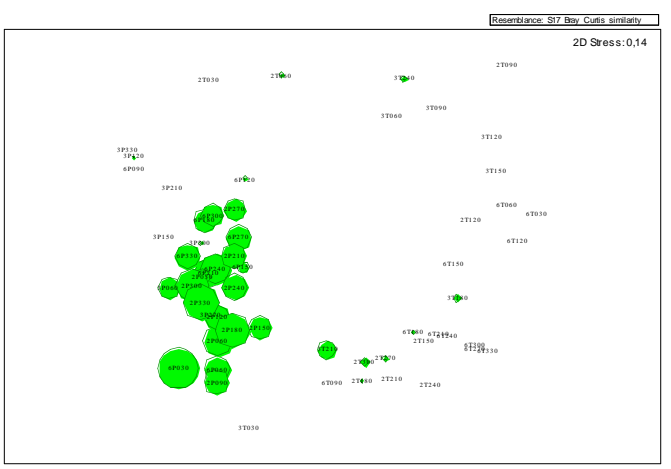

1c. Turf algae

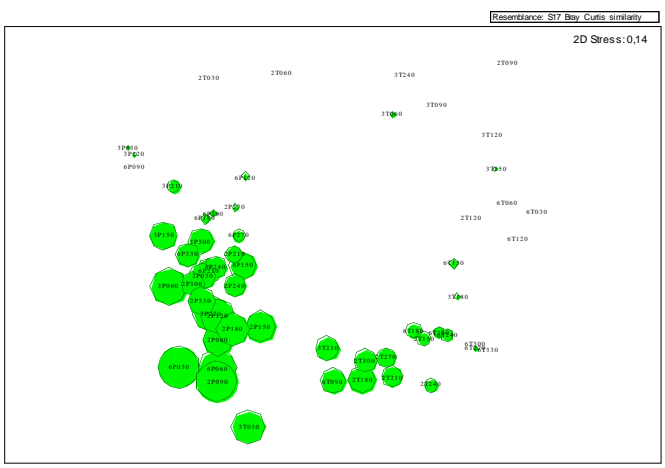

1e. Macroalgae

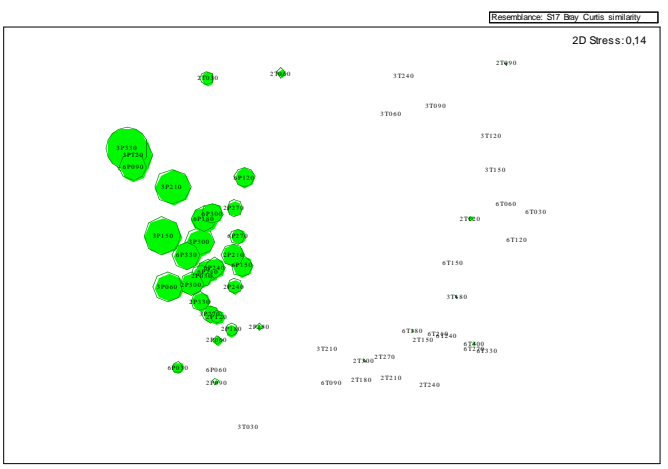

Figure 1b to 1e: Two dimensional-MDS configuration with surimposed bubbles (1993, 1996, 2002 means).

Turfs (t.) dominated at Site-T and macroalgae (m.) at Site-P (T: 75\% turfs / $10 \%$ macroalgae); P: 24\% t./ $52 \%$ m.) (Fig.2a, 2b, Table 2). Cyanophytes and encrusting corallines were much more abundant at Site-P, although they were certainly underestimated by the LIT-method (see discussion).

Table 3: Survey 2 (whole sites, 1993, 1996, 2002): Kruskal-Wallis test between means $(\mu)$ of the variables in the 3 different years, at the two sites ( $\mathrm{T}=$ "Toboggan", $\mathrm{P}=$ "Planch'Alizés") and in the 3 different geomorphologial zones (>: significant increase, <: significant decrease, Ns: non significant).

\begin{tabular}{|c|c|c|c|c|c|c|c|c|}
\hline & & $\begin{array}{l}\mu 1993- \\
\mu 1996\end{array}$ & $\begin{array}{l}\mu 1993- \\
\mu 2002\end{array}$ & $\begin{array}{l}\mu 1996- \\
\mu 2002\end{array}$ & & $\begin{array}{l}\mu 1993- \\
\mu 1996\end{array}$ & $\begin{array}{l}\mu 1993- \\
\mu 2002\end{array}$ & $\begin{array}{l}\mu 1996- \\
\mu 2002\end{array}$ \\
\hline \multirow[t]{6}{*}{ Primary Producers } & $\mathrm{T}$ & Ns & Ns & >>> & $\mathrm{P}$ & $<<<<$ & 《<< & Ns \\
\hline & & & & $\mathrm{p}=0.0000$ & & $\mathrm{p}=0.0000$ & $\mathrm{p}=0.0000$ & \\
\hline & TB & Ns & Ns & $\mathrm{Ns}$ & PB & $<<$ & $<<<$ & Ns \\
\hline & & & & & & $\mathrm{p}=0.0074$ & $\mathrm{p}=0.0007$ & \\
\hline & TL & Ns & Ns & Ns & PL & $<$ & $<<<$ & Ns \\
\hline & $\mathrm{TN}$ & Ns & $\begin{array}{c}\text { >> } \\
\mathrm{p}=0.0006\end{array}$ & $\begin{array}{c}> \\
\mathrm{p}=0.0201\end{array}$ & $\mathrm{PN}$ & $\begin{array}{c}\mathrm{p}=0.0203 \\
< \\
\mathrm{p}=0.0247\end{array}$ & $\begin{array}{c}\mathrm{p}=0.0009 \\
\mathrm{Ns}\end{array}$ & Ns \\
\hline \multirow[t]{5}{*}{ Cyanophytes } & $\mathrm{T}$ & Ns & $<$ & Ns & $\mathrm{P}$ & Ns & 《<< & $\ll$ \\
\hline & & & $\mathrm{p}=0.0313$ & & & & $\mathrm{p}=0.0005$ & $\mathrm{p}=0.0046$ \\
\hline & TB & Ns & $\begin{array}{c}\quad< \\
\mathrm{p}=0.0018\end{array}$ & Ns & PB & Ns & Ns & $\mathrm{Ns}$ \\
\hline & TL & Ns & $\mathrm{Ns}$ & Ns & PL & Ns & $<$ & Ns \\
\hline & $\mathrm{TN}$ & Ns & Ns & Ns & $\mathrm{PN}$ & Ns & $\begin{aligned} \mathrm{p}= & 0.0478 \\
& < \\
\mathrm{p}= & 0.0072\end{aligned}$ & $\begin{array}{c}< \\
\mathrm{p}=0.0156\end{array}$ \\
\hline
\end{tabular}




\begin{tabular}{|c|c|c|c|c|c|c|c|c|}
\hline \multirow[t]{4}{*}{ Total Turfs } & $\mathrm{T}$ & Ns & Ns & $>$ & $\mathrm{P}$ & Ns & $>$ & $>$ \\
\hline & TB & Ns & Ns & $\begin{array}{c}\mathrm{p}=0.0226 \\
\mathrm{Ns}\end{array}$ & $\mathrm{PB}$ & Ns & $\begin{array}{c}\mathrm{p}=0.0291 \\
\mathrm{Ns}\end{array}$ & $\begin{array}{c}\mathrm{p}=0.0068 \\
\mathrm{Ns}\end{array}$ \\
\hline & $\mathrm{TL}$ & Ns & $\begin{array}{c}> \\
\mathrm{p}=0.0424\end{array}$ & Ns & PL & Ns & Ns & Ns \\
\hline & $\mathrm{TN}$ & Ns & $\begin{array}{c}\gg> \\
\mathrm{p}=0.0037\end{array}$ & $\begin{array}{c}\gg> \\
\mathrm{p}=0.0004\end{array}$ & $\mathrm{PN}$ & Ns & Ns & Ns \\
\hline \multirow{4}{*}{$\begin{array}{l}\text { Fine filamentous } \\
\text { turfs }\end{array}$} & $\mathrm{T}$ & Ns & Ns & $\mathrm{Ns}$ & $\mathrm{P}$ & Ns & Ns & $\mathrm{Ns}$ \\
\hline & TB & Ns & Ns & Ns & PB & Ns & $\mathrm{Ns}$ & Ns \\
\hline & $\mathrm{TL}$ & Ns & Ns & Ns & PL & Ns & Ns & Ns \\
\hline & $\mathrm{TN}$ & Ns & Ns & Ns & PN & Ns & Ns & Ns \\
\hline \multirow[t]{4}{*}{$\begin{array}{l}\text { Stegastes } \\
\text { territories }\end{array}$} & $\mathrm{T}$ & Ns & $\begin{array}{c}>> \\
\mathrm{p}=0.0028\end{array}$ & $\begin{array}{c}> \\
\mathrm{p}=0.0278\end{array}$ & $\mathrm{P}$ & Ns & Ns & $\mathrm{Ns}$ \\
\hline & TB & - & - & - & PB & Ns & Ns & Ns \\
\hline & $\mathrm{TL}$ & Ns & $\begin{array}{c}> \\
\mathrm{p}=0.0163\end{array}$ & Ns & PL & Ns & Ns & Ns \\
\hline & $\mathrm{TN}$ & $\begin{array}{c}> \\
\mathrm{p}= \\
0.0384\end{array}$ & $\mathrm{p}=0.0088$ & $\begin{array}{c}>> \\
\mathrm{p}=0.0023\end{array}$ & PN & Ns & Ns & Ns \\
\hline \multirow[t]{4}{*}{$\begin{array}{l}\text { Encrusting } \\
\text { corallines }\end{array}$} & $\mathrm{T}$ & Ns & Ns & Ns & $\mathrm{P}$ & $\begin{array}{c}\text { >>> } \\
\mathrm{p}=0.0000\end{array}$ & $\begin{array}{c}\gg>>> \\
\mathrm{p}=0.0000\end{array}$ & Ns \\
\hline & $\mathrm{TB}$ & Ns & Ns & Ns & PB & Ns & Ns & Ns \\
\hline & $\mathrm{TL}$ & Ns & Ns & Ns & PL & $\begin{array}{c}\gg>> \\
\mathrm{p}=0.0000\end{array}$ & $\begin{array}{c}\gg>> \\
\mathrm{p}=0.0000\end{array}$ & Ns \\
\hline & $\mathrm{TN}$ & Ns & Ns & Ns & PN & $\mathrm{p}=0.0267$ & $\begin{array}{c}\text { >>> } \\
\mathrm{p}=0.0000\end{array}$ & Ns \\
\hline \multirow[t]{4}{*}{ Total Macroalgae } & $\mathrm{T}$ & Ns & Ns & Ns & $\mathrm{P}$ & $\begin{array}{c}<<<< \\
\mathrm{p}=0.0000\end{array}$ & $\begin{array}{c}<<<< \\
\mathrm{p}=0.0000\end{array}$ & Ns \\
\hline & $\mathrm{TB}$ & Ns & $\begin{array}{c}>> \\
\mathrm{p}=0.0033\end{array}$ & $\begin{array}{c}>> \\
\mathrm{p}=0.0033\end{array}$ & PB & $\mathrm{p}=0.0017$ & $\begin{aligned} & <<< \\
\mathrm{p}= & 0.0005\end{aligned}$ & Ns \\
\hline & $\mathrm{TL}$ & Ns & Ns & Ns & PL & Ns & $\begin{array}{c}\quad< \\
\mathrm{p}=0.0016\end{array}$ & Ns \\
\hline & $\mathrm{TN}$ & Ns & Ns & Ns & PN & $\begin{array}{c}< \\
\mathrm{p}=0.0150\end{array}$ & $\begin{array}{c}<< \\
\mathrm{p}=0.0030\end{array}$ & Ns \\
\hline Hypnea valentiae & $\mathrm{T}$ & - & - & - & $\mathrm{PB}$ & $\begin{array}{c}< \\
\mathrm{p}=0.0150\end{array}$ & $\begin{array}{c}<< \\
\mathrm{p}=0.0030\end{array}$ & Ns \\
\hline \multirow{3}{*}{$\begin{array}{c}\text { Lobophora } \\
\text { variegata }\end{array}$} & $\mathrm{T}$ & Ns & Ns & Ns & $\mathrm{P}$ & Ns & Ns & Ns \\
\hline & $\mathrm{TL}$ & Ns & Ns & Ns & PL & $\begin{array}{c}>> \\
\mathrm{n}=00014\end{array}$ & Ns & Ns \\
\hline & $\mathrm{TN}$ & Ns & Ns & Ns & $\mathrm{PN}$ & $\begin{array}{c}> \\
p=0.0150\end{array}$ & Ns & Ns \\
\hline \multirow[t]{3}{*}{ Dictyota spp } & $\mathrm{T}$ & - & - & - & $\mathrm{P}$ & Ns & Ns & Ns \\
\hline & $\mathrm{TL}$ & - & - & - & PL & Ns & $\begin{array}{c}\quad< \\
\mathrm{p}=0.0012\end{array}$ & Ns \\
\hline & $\mathrm{TN}$ & - & - & - & $\mathrm{PN}$ & Ns & $\mathrm{p}=0.0508$ & Ns \\
\hline \multirow[t]{3}{*}{ Padina spp } & $\mathrm{T}$ & - & - & - & $\mathrm{P}$ & Ns & $\mathrm{Ns}$ & Ns \\
\hline & $\mathrm{TL}$ & - & - & - & PL & Ns & $\begin{array}{c}< \\
\mathrm{p}=0.0373\end{array}$ & Ns \\
\hline & $\mathrm{TN}$ & - & - & - & $\mathrm{PN}$ & Ns & $\begin{aligned} & << \\
\mathrm{p}= & 0.0004\end{aligned}$ & Ns \\
\hline \multirow[t]{3}{*}{ Turbinaria ornata } & $\mathrm{T}$ & - & - & - & $\mathrm{P}$ & Ns & Ns & Ns \\
\hline & $\mathrm{TL}$ & - & - & - & PL & Ns & $\mathrm{p}=0.0249$ & $\begin{array}{c}< \\
\mathrm{p}=0.0158\end{array}$ \\
\hline & $\mathrm{TN}$ & - & - & - & $\mathrm{PN}$ & Ns & $\mathrm{Ns}$ & $p=0.0041$ \\
\hline
\end{tabular}

From 1993 to 2002, at Site-T, the total coverage of primary producers (PPcv) increased significantly from 1996 to 2002, although still remaining at low rates (< 
8\%, Fig. 2a). This was mainly due to a turf and macroalgal increase (Table 3). At Site-P, the PPcv regularly decreased from 1993 to 2002 (Fig. 2a, 2b), due to a significant decrease in Cyanophytes and macroalgae coverage. By contrast, turf and encrusting coralline coverage increased significantly.
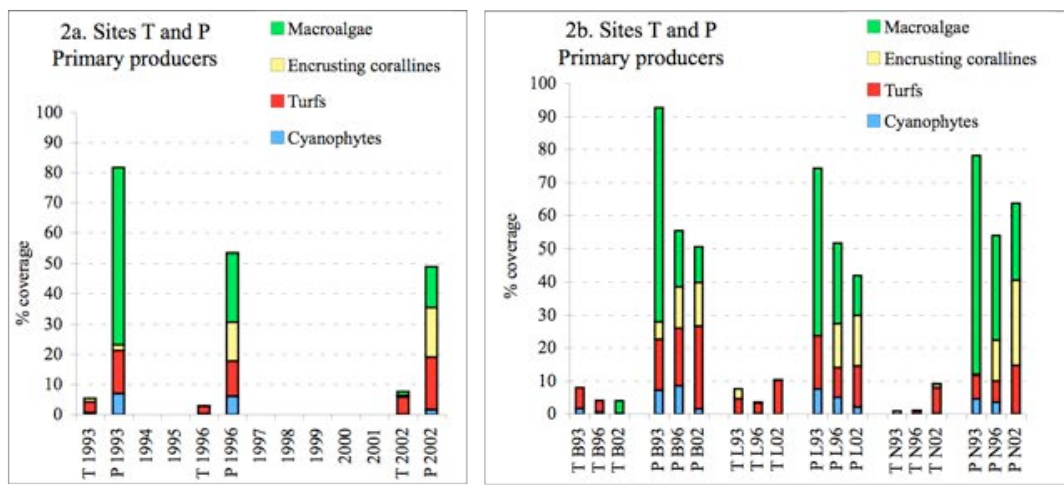

Figure 2a \& 2b: Spatio-temporal variation from 1993 to 2002 of the coverage of the 4 groups of primary producers. Left : for the total site, right: in the three geomorphological zones, $\mathrm{B}=$ back reef, $\mathrm{L}=$ inner zone of Large coral strips, $\mathrm{N}=$ outer zone of Narrow coral strips.

Cyanophytes. On average, the Cyanophyta coverage was 16 times higher at Site-P (Table 2). At both sites, Cyanophytes significantly decreased over time (Fig. 2c, 2d, Table 3).

At Site-T, a significant temporal decrease was observed in the back reef zone. However, given that all the Cyanophytes recorded on Site-T were highly ephemeral in time, these variations are not likely to be meaningful.

By contrast, at Site-P, the cyanophytes were less ephemeral. They declined significantly between 1993 and 2002 in the PL and PN subzones. One of them, Lyngbya majuscula showed no significant variation between 1993 and 2002 and remained perennial in the PL-coral zone. It grows attached to corals, in mats of fine, dark, cotton wool-like strands 10 to 30 centemeters long. When Lyngbya is présent in large amounts, it accumulâtes gaz bubbles around the filaments (from High rates of photosynthesis). At PL, it invaded framework cavities of Montipora circumvallata and Porites (Synaraea) rus colonies, that, as a result, grew up in the form of candles. Its coverage is extremely under-estimated from the line-transect method. L. majuscula has never been recorded nor observed at Site-T. 

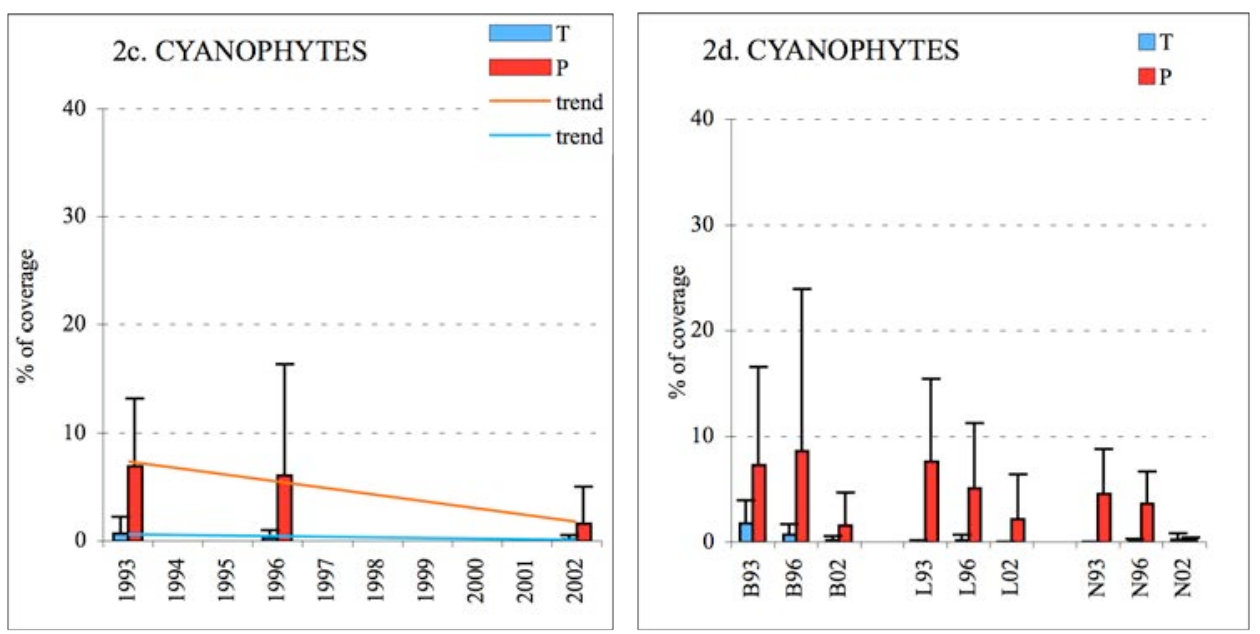

Figure 2c \& 2d: Spatio-temporal variation from 1993 to 2002 of the coverage of Cyanophytes. Left : for the total site, right: in the three geomorphological zones.

Turf algae. Their coverage never exceeded 5\% at Site-T and is three times higher at Site-P (Table 2). Among turfs, fine filamentous turfs (AG) were prevalent in the back reef zone at both sites, and in the PN outer coral zone. Stegastes territories (AGS) were dominating in the whole coral zone ( $\mathrm{L}$ and N) at Site-T, but only in the L-zone at Site-P (Fig. 2e).

Outer turfs (AGE) were only observed in the outer PN coral zone. These turfs were mostly formed by Amphiroa fragilissima, Jania adhaerens, Actinotrichia fragilis. A mixture of Gelidiella acerosa, Gelidium pusillum, Gelidiopsis intricata filled up the interstices. These pads were often epiphyted by macroalgae, such as Dictyosphaeria cavernosa. They were not abundant enough to allow investigation of their temporal variation.
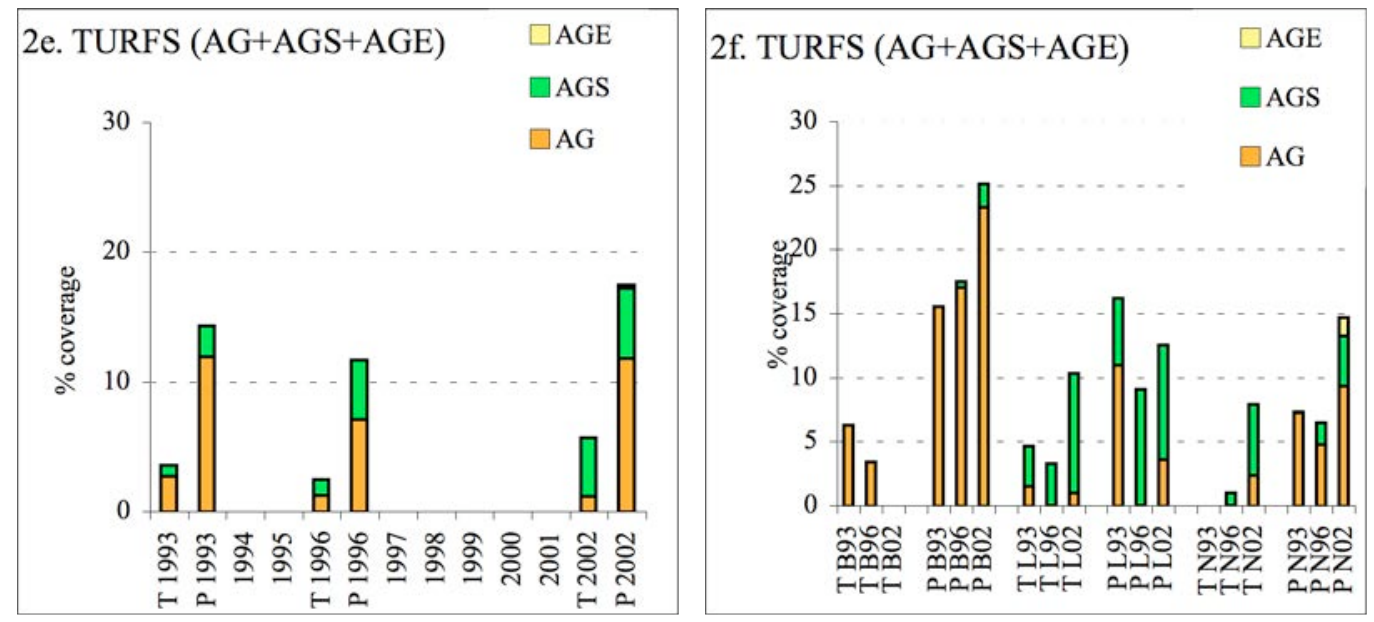

Figure 2e \& 2f: Spatio-temporal variation from 1993 to 2002 of the coverage of turfs (AG+AGS+AGE). AGE: outer turfs, AGS: Stegastes territories, AG: fine filamentous turfs. Left: for the total site, right: in the three geomorphological zones. 

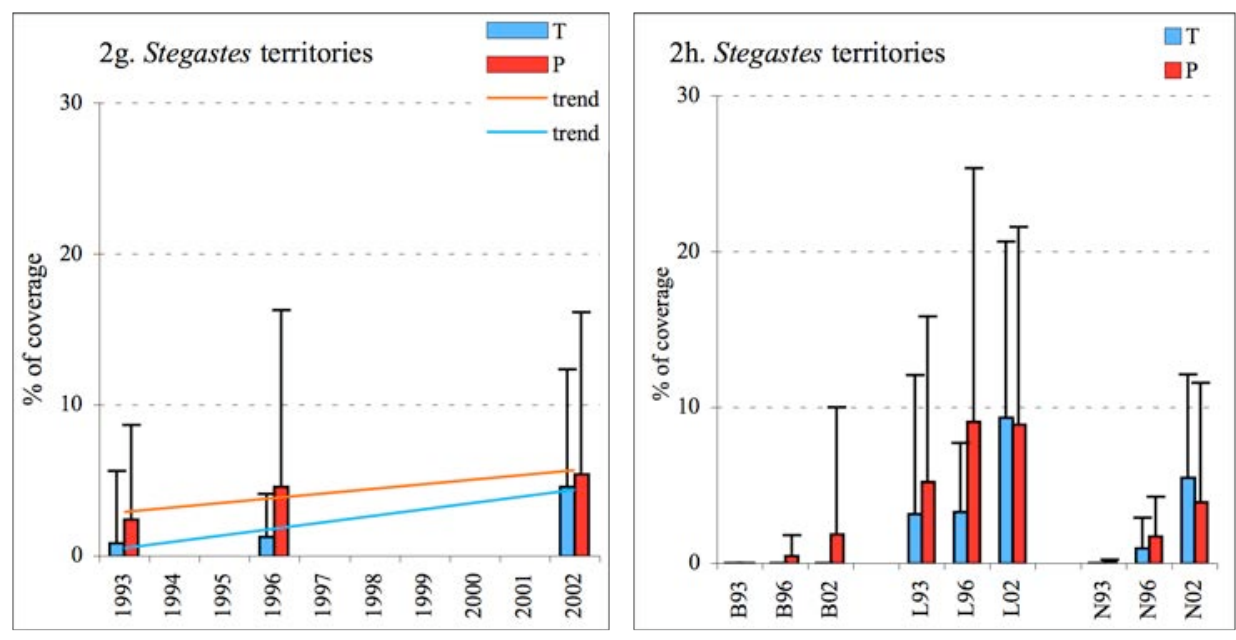

Figure 2g \& 2h: Spatio-temporal variation from 1993 to 2002 of the coverage of Stegastes territory turfs. Left: for the total site, right: in the three geomorphological zones.

At Site-T, turf abundance increased significantly between 1993 and 2002 (Fig. 2e; Table 3), due to the expansion of Stegastes territories over time in the coral zones, TL and TN (Fig. 2g, 2h).

At Site-P, turfs also increased in abundance through time, although this increase was not obvious (Table 3). In the whole coral zone $(\mathrm{L}+\mathrm{N})$, the coverage of Stegastes territories did not vary significantly.

Encrusting corallines. They appeared almost absent at Site-T, while locally abundant at Site-P (Table 2). Considering the temporal variation at Site-P (Fig. 2i, $\mathbf{2 j}$ ), encrusting coralline coverage increased significantly in the coral zone, PL and PN, from 1993 and 1996, and non significantly in the back reef zone (Table 3).
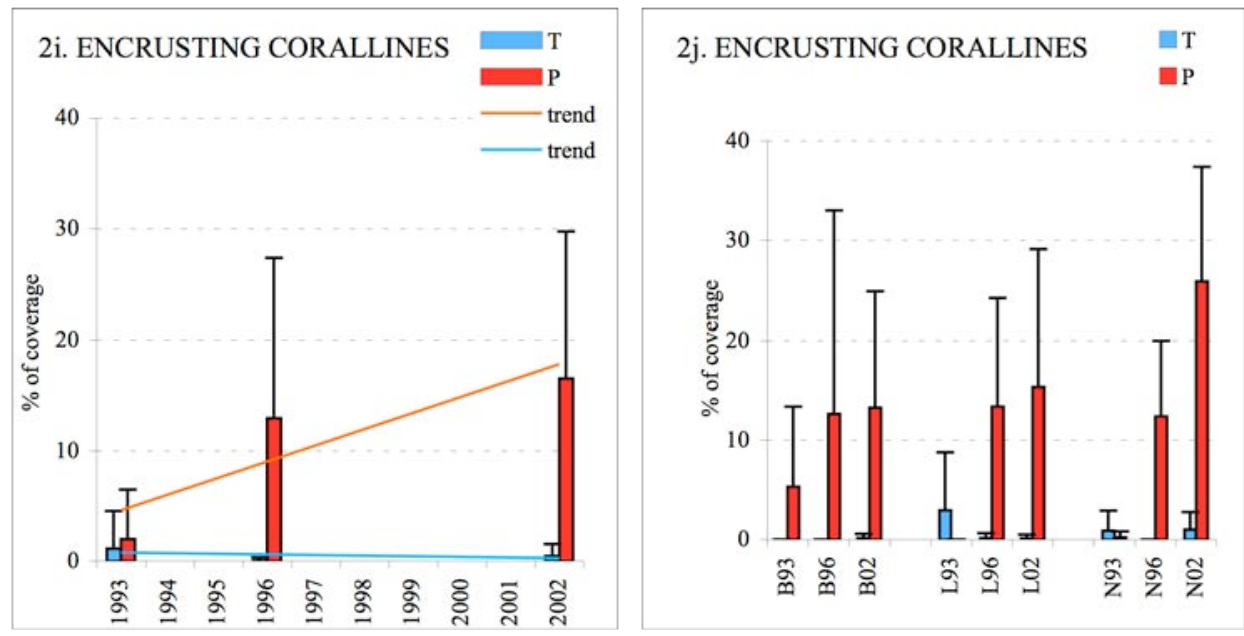

Figure 2i \& 2j: Spatio-temporal variation from 1993 to 2002 of the encrusting corallines. Left : for the total site, right: in the three geomorphological zones.

Macroalgae. Inconspicuous at Site-T, macroalgae were abundant at Site-P (Table 2). The general trend shows a drastic and significant decrease in macroalgae between 1993 and 1996 in PB and PN sub-zones, and, between 1993 and 2002, in the 3 P-subzones (Fig. 2k, 2l, Table 3). While in 1993, macroalgae occurred as monospecific beds about c. 1 to $10 \mathrm{dm}$ diameter, in 2002, they rather form small 
patches about c. 1 to $5 \mathrm{~cm}$ diameter and/or in intimate species assemblage (called "mixed macroalgae", fig. 21 bis).

At Site-P, all the dominant soft macroalgae declined in different ways from 1993 to 2002 (Table 3; Hypnea valentiae: Fig. 2m, 2n, Padina spp: Fig. 2o, 2p,

Dictyota spp: Fig. 2s \& 2t, Turbinaria ornata: Fig. 2u, 2v, Gracilaria canaliculata: Fig. 2w, 2x). On the coral zone (PL+PN), the demise of these macroalgae benefited the encrusting Lobophora variegata (Fig. 2q, 2r), which, like many encrusting corallines, covered the underlying substrate. At both sites, Lobophora variegata occurred as dark-chocolate crusts made up of massive blades, strongly adhering to the subtidal substratum. However, at Site-P, upward-growing blades were also observed on vertical walls of coral cavities.
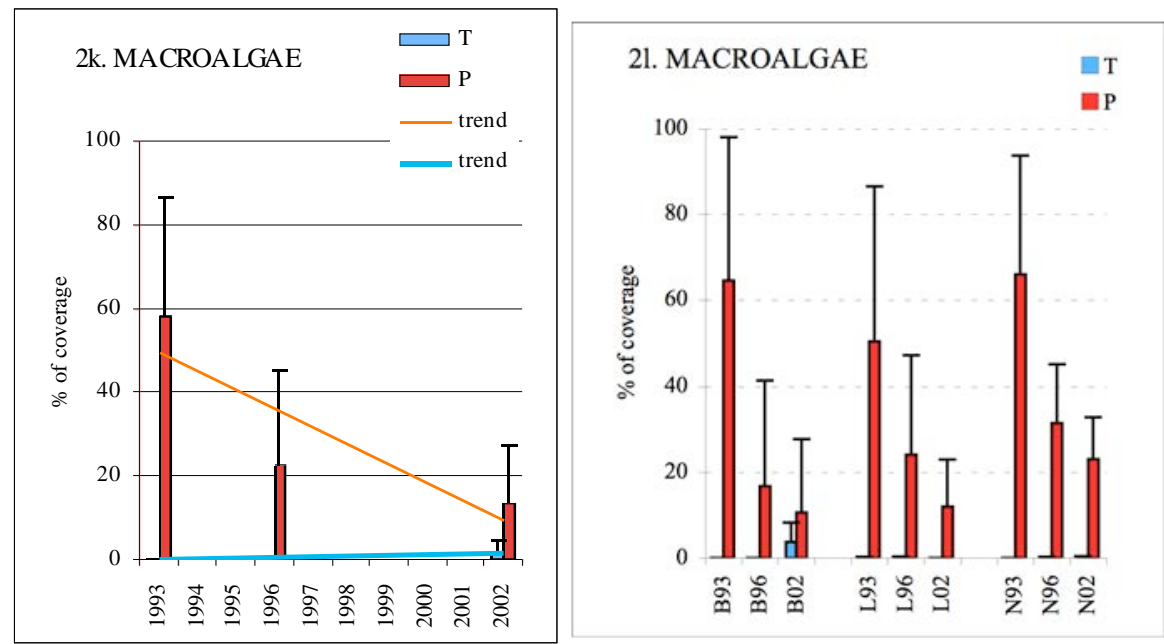

Figure 2k \& 21: Spatio-temporal variation from 1993 to 2002 of macroalgae. Left : for the total site, right and below: in the three geomorphological zones.

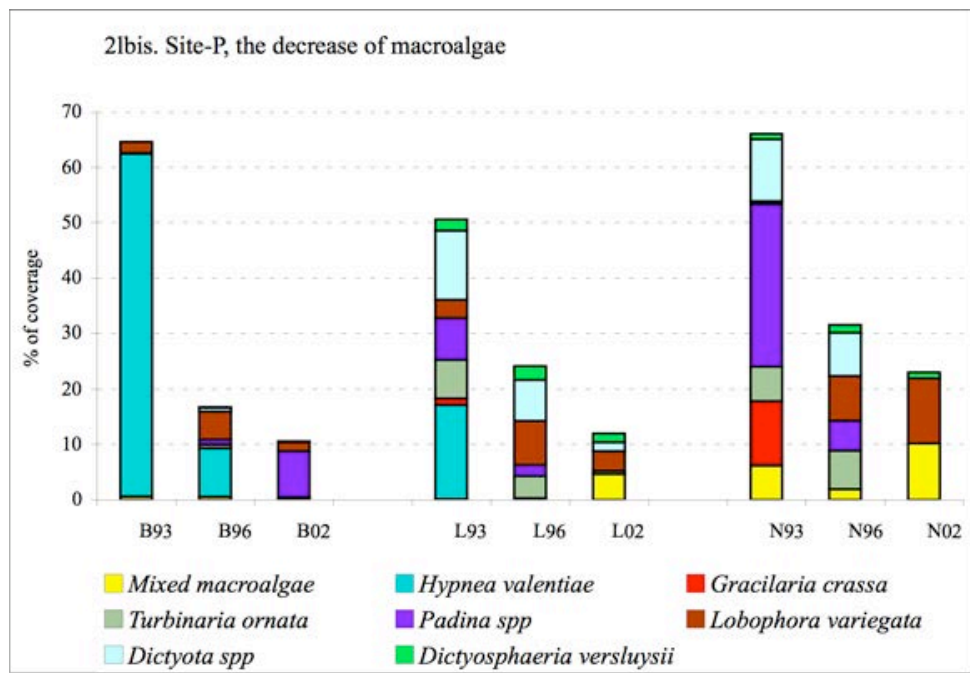

Figure 2lbis: Site-P: spatio-temporal variation from 1993 to 2002 of the dominant species of macroalgae in the three geomorphological zones. 

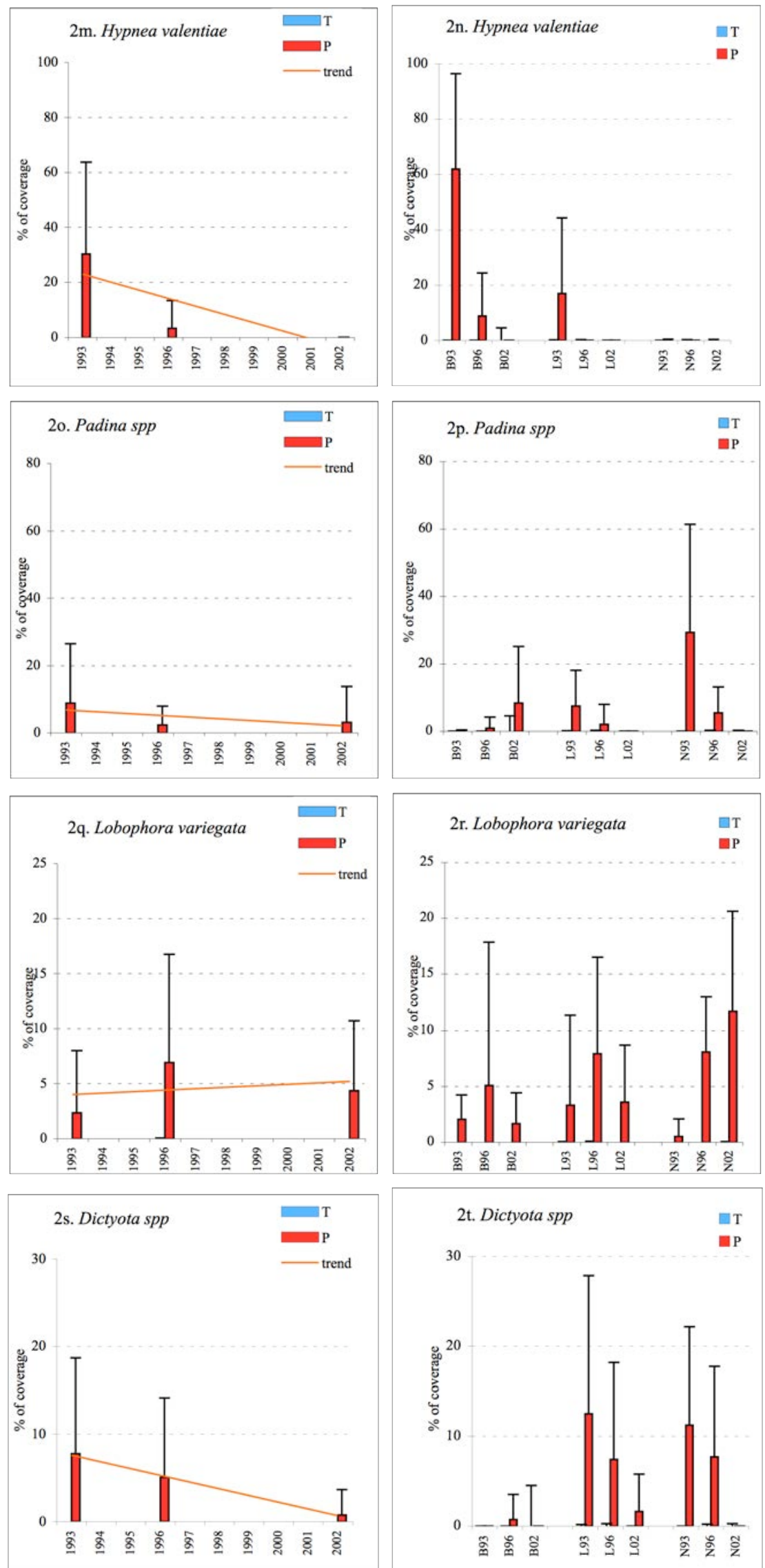

Figure 2m to 2t: Spatio-temporal variation from 1993 to 2002 of the dominant species of macroalgae. Left : for the total site, right: in the three geomorphological zones. 

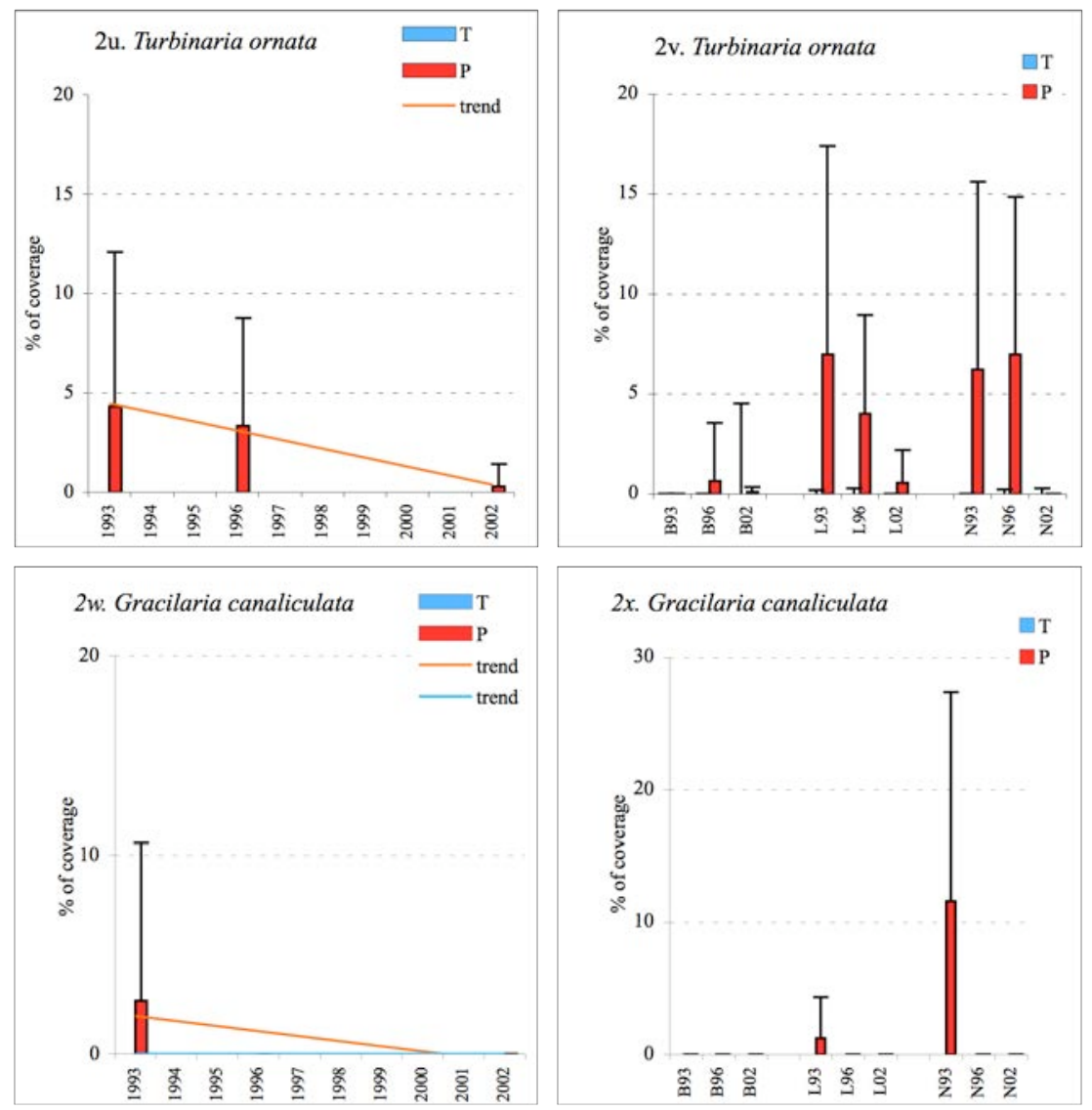

Figure 2u to 2x: Spatio-temporal variation from 1993 to 2002 of the dominant species of macroalgae. Left : for the total site, right: in the three geomorphological zones.

Survey 2: the permanent transects T180m, P270m from 1987 to 2009

As in Tourrand et al. (2013), the monitoring time was divided into 3 periods: 1987-98, 1999-2003, 2004-2009. At T180, the permanent transect on Site-T (Table 1), the turfs increased significantly from 1987-98 to 2004-09 (Fig. 3b, Table 4) while at P270, the permanent transect on Site-P, macroalgae decreased significantly in abundance between the two periods (Fig. 3d).

Table 4: Study 4 (GCRMN data): Kruskal-Wallis test between means $(\mu)$ of the variables in the 3 "year-blocks", on the two permanent transects (T180= "Toboggan" $180 \mathrm{~m}$ off shore, $\mathrm{P}=$

"Planch'Alizés", 270 m off shore) (>: significant increase, <: significant decrease, Ns: non significant).

\begin{tabular}{|c|c|c|c|c|c|c|c|c|}
\hline & & $\begin{array}{c}\mu(1987- \\
1998) \\
-\mu(1999- \\
2003)\end{array}$ & $\begin{array}{c}\mu(1999- \\
2003) \\
-\mu(2004- \\
09)\end{array}$ & $\begin{array}{c}\mu(1987- \\
1998) \\
-\mu(2004- \\
09)\end{array}$ & & $\begin{array}{c}\mu(1987- \\
1998) \\
-\mu(1999- \\
2004)\end{array}$ & $\begin{array}{c}\mu(1999- \\
2003) \\
-\mu(2004- \\
09)\end{array}$ & $\begin{array}{c}\mu(1987- \\
1998) \\
-\mu(2004- \\
09)\end{array}$ \\
\hline Primary Producers & T180 & Ns & Ns & $\begin{array}{c}>> \\
\mathrm{p}=0.0019\end{array}$ & $\mathrm{P} 270$ & $\begin{array}{c}< \\
\mathrm{p}=0.0373\end{array}$ & Ns & Ns \\
\hline Turfs & & Ns & Ns & $\begin{array}{c}>> \\
\mathrm{p}=0.0024\end{array}$ & & Ns & Ns & Ns \\
\hline $\begin{array}{l}\text { Encrusting } \\
\text { coralline }\end{array}$ & & Ns & Ns & Ns & & Ns & Ns & Ns \\
\hline Macroalgae & & Ns & Ns & Ns & & Ns & Ns & $\begin{array}{c}<< \\
\mathrm{p}=0.0055\end{array}$ \\
\hline
\end{tabular}



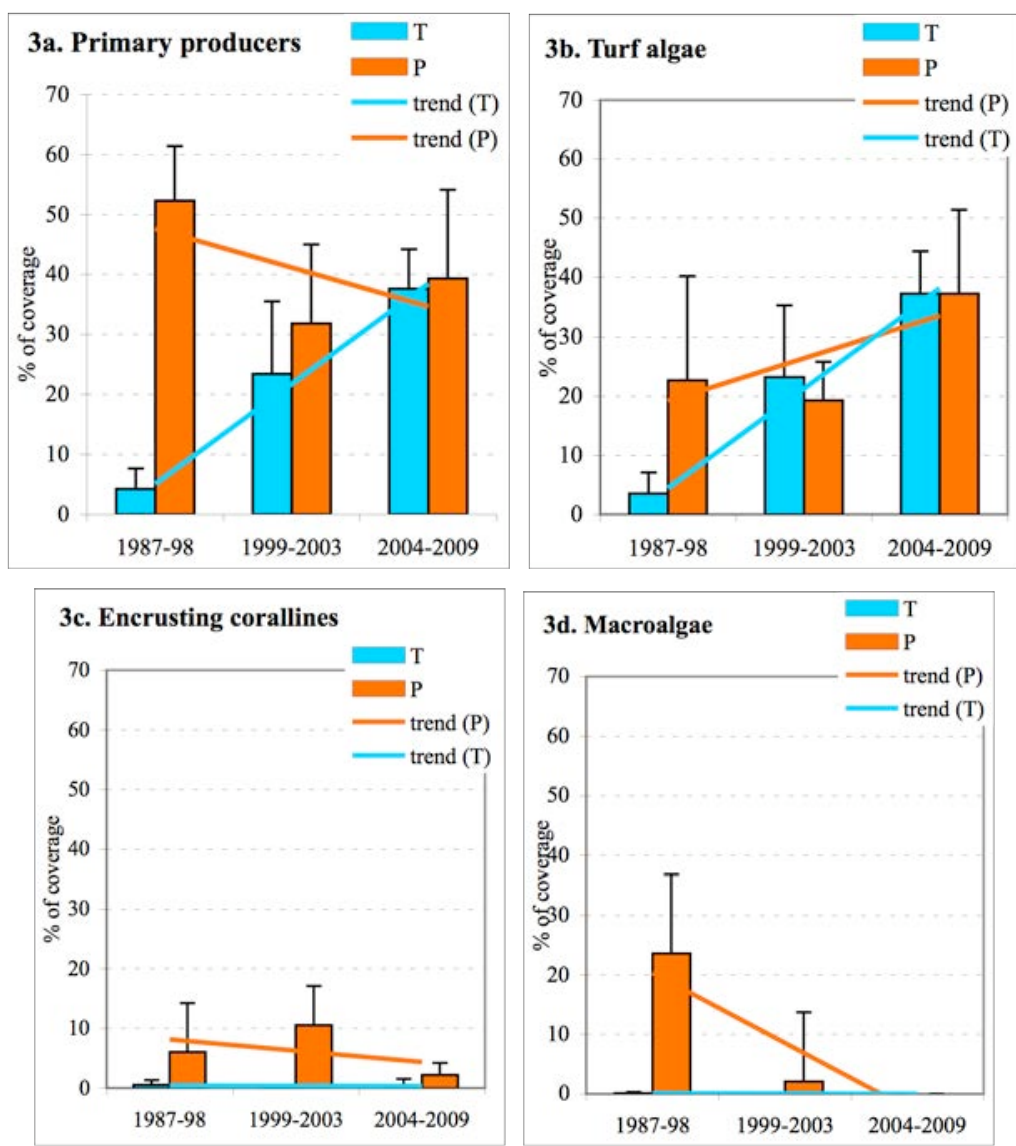

Figure 3a to 3d: Temporal variation of primary producers, turfs, encrusting corallines and macroalgae coverage between 1987-98, 1999-2003 and 2004-2009 "year-blocks".

For both turfs and macroalgae, the 1999-2003 mean coverage was intermediate, and not significantly different from 1987-98 and 2004-09 mean values. Due to high variance, the encrusting coralline mean coverage at P270 did not display any significant temporal variation.

Survey 3: species richness of algae and diversity

Table 5 includes all the species recorded at the 3 stations from each site. Among these species, in terms of occurrence recorded at the highest (infracentimeter) resolution, Hydrolithon onkodes and Lobophora variegata dominated over the algal community, both encrusting most of the intertidal substrates at both sites and in all the subzones. Jania adhaerens was also one of the very common algae, forming low turfs on flat substrates.

In the back reef, $\mathrm{TB}$, the small Gelidium pusillum, a species of Melobesiae (unidentified, encrusting the pavement), together with Jania adhaerens dominated over the community. In the coral zone, the Hydrolithon onkondes-Lobophora variegata association was dominating in TL (followed by Polysiphonia mollis and Anotrichium tenue, both belonging to Stegastes territories), while Jania adhaerens and Dictyosphaeria versluysii dominated in TN.

The PB subzone was dominated by Mesophyllum erubescens, which overcapped dead hard substrates and coral rubble of c. $10 \mathrm{~cm}$ maximum diameter, thus forming numerous rhodoliths. In the PL subzone, Lyngbya majuscula was the 
most common species, in association with Hydrolithon onkodes, Blennothrix cantharidosma and Lithophyllum kotschyanum. In the PN outer subzone, Jania adhaerens, Hydrolithon onkodes and Gelidiella acerosa dominated, both filamentous species forming part of the "outer turfs".

Species richness appeared to be higher at Site-P (Fig. 4). It increased from the back reef seawards. Among subzones, PN was the richest in species and occurrence of algae.

Table 5: List of species of algae recorded at the two sites and their occurrence in subquadrats (Exemple: $20=$ occurrence in $20\{5 \mathrm{~cm} \times 5 \mathrm{~cm}\}$ subquadrats of one species at one site. CYAN= Cyanophyta, $\mathrm{CHL}=$ Chlorophyta, $\mathrm{OCH}=$ Ochrophyta $($ Paeophyceae $), \mathrm{RHO}=$ Rhodophyta.

\begin{tabular}{|c|c|c|c|c|c|}
\hline & PHYLUM & FAMIILY & SPECIES & $\mathrm{T}$ & $\mathrm{P}$ \\
\hline 1 & Cyanophytes & Oscillatoriaceae & Lyngbyamajuscula & 20 & 441 \\
\hline 2 & “ & Phormidiaceae & Blennothrix cantharidosma & 219 & 334 \\
\hline 3 & “ & Phormidiaceae & Leptolyngbyacrosbyana & 6 & 4 \\
\hline 4 & “ & Schizotrichaceae & Schizothrix calcicola & 29 & 25 \\
\hline 5 & Chlorophytes & Bryopsidaceae & Bryopsissp. & 0 & 6 \\
\hline 6 & “ & Caulerpaceae & Caulerpanummularia & 0 & 15 \\
\hline 7 & “ & Caulerpaceae & Caulerpa racemosa & 0 & 25 \\
\hline 8 & “ & Caulerpaceae & Caulerpa serrulata & 0 & 3 \\
\hline 9 & “ & Codiaceae & Codiumarabicum & 2 & 0 \\
\hline 10 & “ & Codiaceae & Codium bartlettii & 1 & 0 \\
\hline 11 & “ & Derbesiaceae & Derbesiasp. & 0 & 12 \\
\hline 12 & “ & Cladophoraceae & Cladophorapatentiramea & 0 & 1 \\
\hline 13 & “ & Cladophoraceae & Cladophora sibogae & 5 & 17 \\
\hline 14 & “ & Cladophoraceae & Rhizoclonium grande & 3 & 6 \\
\hline 15 & “ & Dasycladaceae & Bornetella sphaerica & 2 & 6 \\
\hline 16 & “ & Dasycladaceae & Neomeris annulata & 2 & 1 \\
\hline 17 & “ & Dasycladaceae & Neomeris van bosseae & 0 & 1 \\
\hline 18 & “ & Polyphysaceae & Parvocaulis parvulus & 22 & 5 \\
\hline 19 & “ & Boodleaceae & Boodlea composita & 0 & 2 \\
\hline 20 & “ & Boodleaceae & Phyllodictyon anastomosans & 0 & 1 \\
\hline 21 & “ & Siphonocladaceae & Boergeseniaforbesii & 47 & 14 \\
\hline 22 & “ & Siphonocladaceae & Cladophoropsis herpestica & 0 & 38 \\
\hline 23 & “ & Siphonocladaceae & Dictyosphaeriacavernosa & 34 & 206 \\
\hline 24 & “ & Siphonocladaceae & Dictyosphaeriaversluysii & 393 & 349 \\
\hline 25 & “ & Valionaceae & Ernodesmis verticillata & 2 & 2 \\
\hline 26 & “ & Valionaceae & Valoniamacrophysa & 12 & 7 \\
\hline 27 & “ & Valionaceae & Valonia ventricosa & 8 & 8 \\
\hline 28 & “ & Valionaceae & Valoniopsis pachynema & 0 & 10 \\
\hline 29 & “ & Ulvaceae & Ulvaclathrata & 9 & 14 \\
\hline 30 & “ & Ulvaceae & Ulvafasciata/lactuca & 0 & 1 \\
\hline 31 & Ochrophyta & Dictyotaceae & Dictyotafriabilis & 0 & 15 \\
\hline 32 & “ & Dictyotaceae & Dictyota humifusa $(c f)$ & 1 & 166 \\
\hline 33 & “ & Dictyotaceae & Dictyopteris delicatula & 0 & 1 \\
\hline 34 & “ & Dictyotaceae & Lobophoravariegata & 760 & 818 \\
\hline 35 & “ & Dictyotaceae & Padinaboryana & 122 & 279 \\
\hline 36 & “ & Sargassaceae & Turbinaria ornata & 176 & 151 \\
\hline 37 & “ & Chnoosporaceae & Chnoosporaimplexa & 1 & 0 \\
\hline 38 & “ & Scytosiphonaceae & Hydroclathrus clathratus & 2 & 4 \\
\hline 39 & “ & Sphacelariaceae & Sphacelarianovae-hollandiae & 187 & 0 \\
\hline 40 & “ & Sphacelariaceae & Sphacelariatribuloides & 5 & 16 \\
\hline 41 & Rhodophyta & Corallinaceae & Amphiroafragilissima & 113 & 225 \\
\hline 42 & “ & Corallinaceae & Janiaadhaerens & 460 & 548 \\
\hline
\end{tabular}




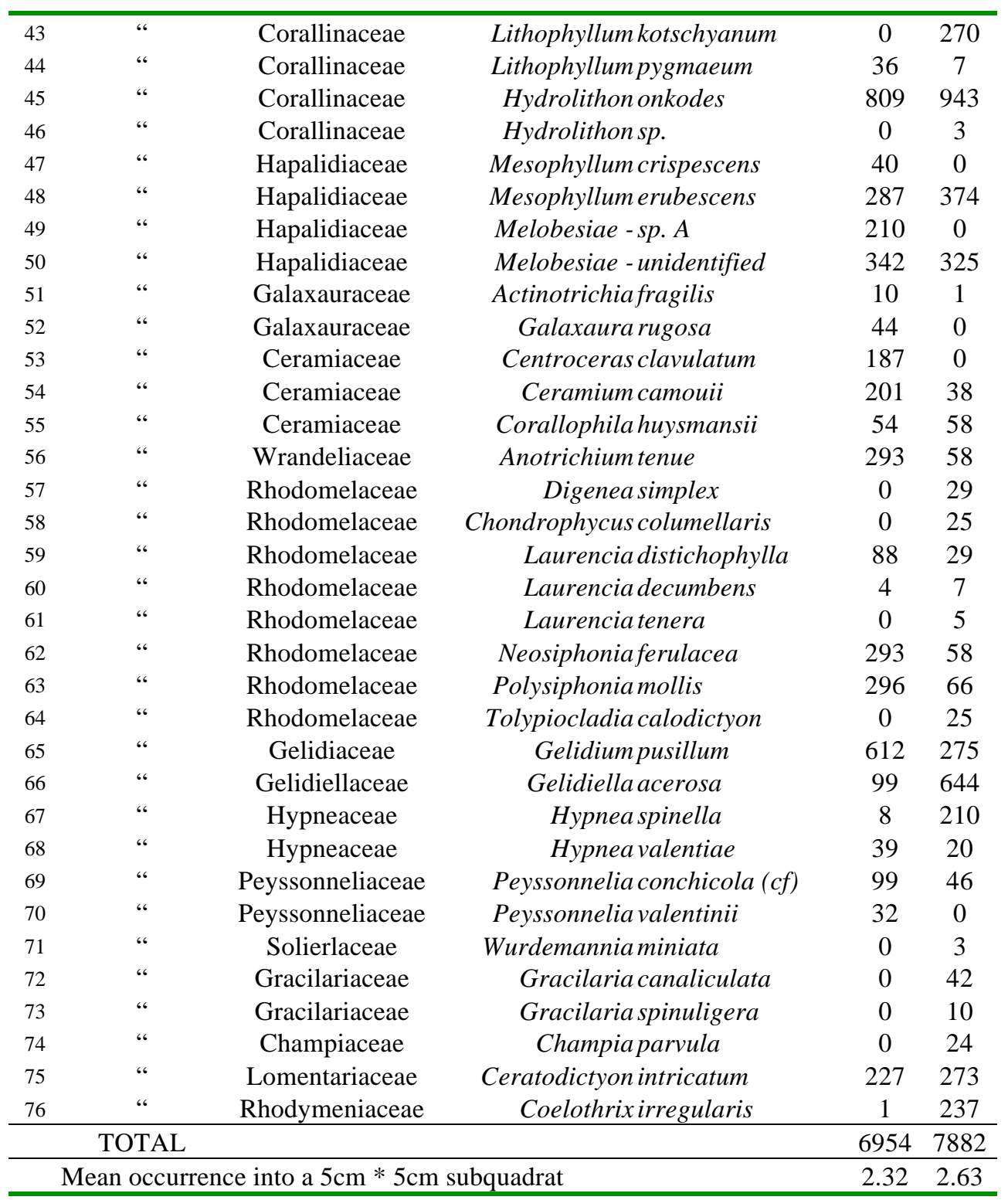

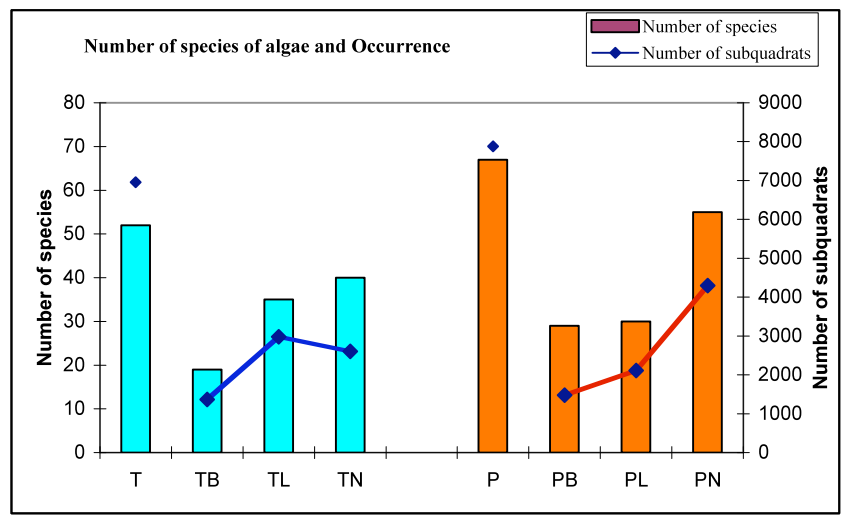

Figure 4: Survey 3: Number of species of algae and occurrence in small subquadrats $(5 \mathrm{~cm} x 5 \mathrm{~cm}$; see table 2), at the two sites $\mathrm{T}$ and $\mathrm{P}$. 


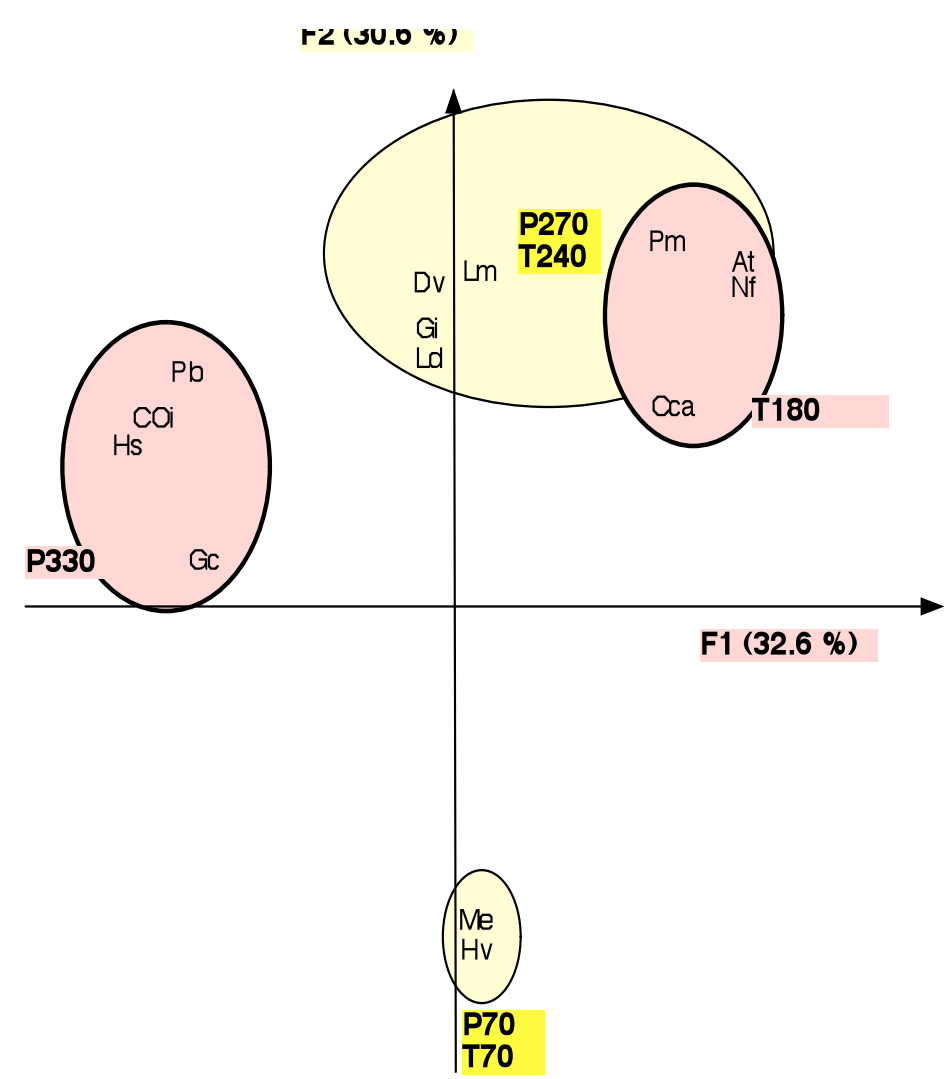

Figure 5: Survey 3: Principal component analysis on dataset 3, F1/F2. T180 (TL): At: Anotrichium tenue, Nf: Neosiphonia ferulacea, Cca: Ceramium camouii, Polysiphonia mollis, P330 (PN): Hs:

Hypnea spinella, COi: Coelothrix irregularis, Pb: Padina boryana, Gc: Gracilaria canaliculata, T240 (N-zone), P270 (PL): P. mollis, A. tenue, N. ferulacea,T70 (TB) and P70 (PB): Rhizoclonium grande, unidentified Melobesiae, Hypnea valentiae, Mesophyllum erubescens.

The algal diversity, depending on the occurrence of each species in the subquadrats (and not abundance), in the form of the Shannon Weaver index ( $\mathrm{H}^{\prime} \mathrm{Log}$ ) was approximately the same at both sites (T: 3.143, P: 3.196), as well as in subzones B, L, N (Fig. 4). The principal component analysis applied on the 6 subzones data shows (Fig. 5) that Factor 1, the most explanatory factor (32.6\% of the variance), opposes a community typified by the occurrence of Stegastes turfs (including Anotrichium tenue, Neosiphonia ferulacea, Ceramium camouii, Polysiphonia mollis) on P270 and T180 transects (PL and TL zones respectively) to algae present on P330 (PN subzone), represented by macroalgae and outer turfs (Hypnea spinella, Coelothrix irregularis, Padina boryana, Gracilaria canaliculata). Factor $2(30.6 \%$ of the variance) opposes also the Stegastes turf community (P. mollis, A. tenue, $N$. ferulacea) on P270 (PL) and T240 (TN) to a community of algae composed of Rhizoclonium grande, an unidentified Melobesiae, Hypnea valentiae, Mesophyllum erubescens mostly characterizing the T70 and P70 back reefs. Similarly, Factor 3 (21.2\% of the variance, not shown) opposes the "turfs" variables (C. camouii, Gelidiella acerosa) on P270 and T180 (PL and TL subzones respectively) to a specific assemblage (Centroceras clavulatum, Sphacelaria novae-hollandiae, Galaxaura rugosa) only observed on T240 (TN). Differences in the algal community composition therefore appear to be more explained by reef morphological attributes than by ecological differences between Sites $T$ and $P$. Epilithic algal species belonging to Stegastes territories are often segregating the stations.

Survey 4: Biomass (monthly variation) of dominant species of macroalgae

The back reef (B-zone). The macroalgal biomass was significantly different between the two sites only in January (p <0.01) (Fig. 6a, 6b). The peak of biomass was due to the development of Hypnea valentiae in February (Fig. 6e, 6f). 

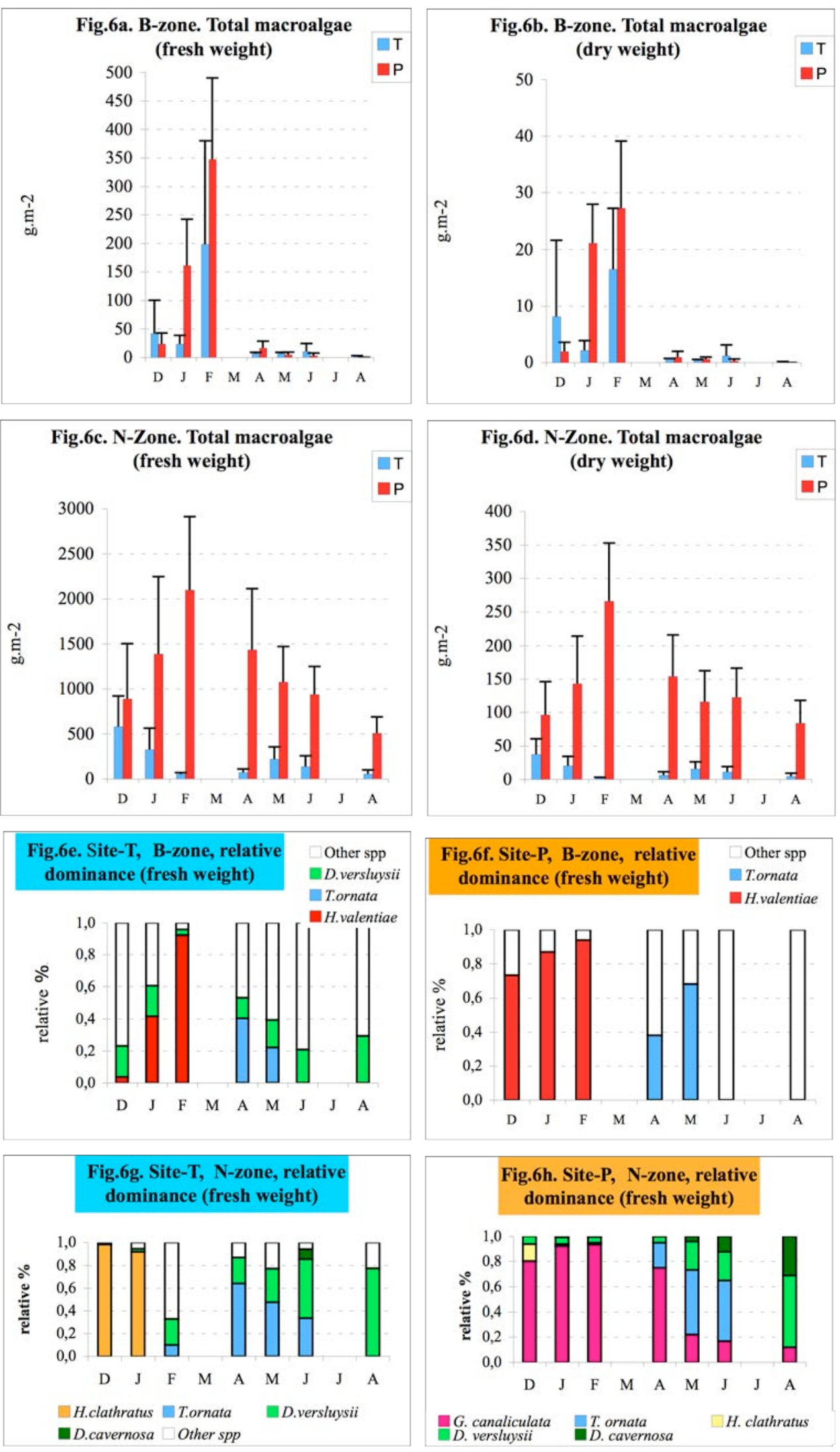

Figure 6a to 6h: Biomass (fresh \& dry weight) and relative dominance (fresh weight) of the dominant species of macroalgae in fresh and weight at Site- $\mathrm{T}$ and Site-P (T= "Toboggan"; P= "Planch'Alizés"), from December 1992 to August 1993, in the back reef (B-zone) and narrow coral strip zone (N-zone). 
Dictyosphaeria versluysii, also dominant in the $\mathrm{T}$ back reef, appeared to be absent from P-back reef wheras it was only hidden by the Hypnea valentiae large thalli.

The outermost $\mathbf{N}$-zone. The biomass was significantly different from month to month between the two sites, except in December (Fig.6c, 6d). At Site-T, in summer (December to March), the peak of biomass resulted from the appearance of Hydroclathrus clathratus (Fig. 6g). In Reunion, this Phaeophyceae blooms in December, declines in January and disappears in February. In this oligotrophic environment, Boodlea composita was also observed forming patches of up to around $10 \mathrm{~cm}$ diameter (not recorded on LITs). At Site-P, H.clathratus was almost absent while Gracilaria canaliculata not only dominated over the community but persisted throughout the year (Fg. 6h). Dictyosphaearia versluysii and D. cavernosa were prevalent in winter, the first of these mainly occurring at intertidal locations. In autumn, Turbinaria ornata in turn became prevalent and dominated the subtidal coral zone, although its development was partly hindered by that of Gracilaria canaliculata in the outer PN subzone.

\section{DISCUSSION}

Behaviour of the four groups of primary producers from 1993 to 2009: coverage (LITs) and biomass

Cyanophytes. From 1993 to 2002, Cyanophytes were 14 times more abundant in coverage at Site-P than at Site-T. The dominant species recorded at Site-P, Lyngbya majuscula, was totally absent at Site-T and its coverage showed no significant variation over this period. In addition, L. majuscula was and is still perennial at Site-P, even in winter. Schizothrix calcicola, the second dominant Cyanophyte, occurred in summer blooms in the back reef areas in both sites. Rare in the $\mathrm{T}$ back reef, it can be locally abundant in the $\mathrm{P}$ back reef and become invasive when reef waters are warm and calm.

Cyanophytes are capable of nitrogen fixation (Burris, 1976; Potts \& Whitton, 1977) and may therefore contribute to the nitrogen enrichment of waters (Baravetza \& Larkum, 1986). Miller et al. (1999), testing the effects of nutrient enrichment on coral communities, showed that the development of filamentous cyanophytes was enhanced by increasing nutrient levels.

On the Saint-Gilles La Saline reef flat, Lyngbya majuscula is abundant in the PL subzone and in other MAS coral zones (such as Site-"Club Med") but absent or extremely rare at Site-T and other ACR communities (such as Site-"Petit Trou d'eau"). As temperature is higher on reef flats subject to outgoing reef waters (see part 1), L. majuscula may be considered at Reunion as a bioindicator of a dystrophy, linked to freshwater inputs and local temperature increase. Morrow et al. (2011) revealed that extracts of two Lyngbya species strongly stimulate microorganisms at the surface of coral colonies. Furthermore Lyngbya is a potentially toxic, marine cyanobacterium. Then, at Reunion, Lyngbya can contribute to the decrease of sensitive corals such as Acropora in MAS communities by increasing the coral susceptibility to disease and/or by being toxic.

Over recent decades, Lyngbya blooms have increased in tropical and subtropical régions around the world. In Australia, the key environmental conditions 
for Lyngbya growth (http://www.ehp.qld.gov.au/coastal/ecology/lyngbyaupdates/index.html) appear to be the presence of bio-available nutrients such as phosphorus, nitrogen and iron, disolved oragnic matter and favourable light, salinity and temperature conditions $\left(>24^{\circ} \mathrm{C}\right)$ in the environnement.

Turf algae. Fine filamentous turfs (AG) did not vary significantly in coverage from 1993 and 2002.

From 1993 to 2002, the coverage of Stegastes damselfish territory turfs was stable at Site-P while they were steadily increasing at Site-T. Among Stegastes species, Stegastes nigricans was dominant (Tourrand et al., 2013). In the epilithic algal communities defended by Stegastes nigricans, Lison de Loma \& Ballesteros (2002) recorded, at both Site-T and Site-P, one Cyanophyte, eight Chlorophytes, fifteen Rhodophytes, and four Ochrophytes, and showed that the assemblage was different between sites.

Stegastes nigricans preferentially establishes its territory at the top of the branches of Acropora. During this 9 year-period, at Site-T, as Acropora coverage increased steadily, the density of Stegastes associated turfs similarly increased (Fig. 2g). Indeed, this fish takes advantage of any mortality due to prolonged air exposure or a bleaching event (Letourneur et al., 1983). From 1987-98 to 2004-2009, at Site-T, the turf coverage continued to increase significantly. At PL subzone, a shift in primary producer composition occurred: in 1997-98, turfs and macroalgae represented 43 and 45\% of PPcv respectively, while in 2004-2009, turfs represent $94 \%$ of the PPcv, and macroalgae have disappeared. These results reflect a shift in abiotic conditions, and particularly a decrease in nutrient supply at Site-P (see below).

Concerning outer turfs (AGE), these are not abundant enough to be taken into account. Nevertheless, the "outer turf assemblage" made up of dominant articulated corallines (see details about the species composition in the "Results" section) only occurred on the PN outer coral zone. Now, in Reunion, this assemblage often signals a freshwater input on the reef flat zones, such as Saint-Leu city, Etang-salé, and particularly Saint-Pierre, where it can form a clearly differentiated facies (Cuet 1989a; Naim, 1989).

Encrusting corallines. As calcite depositors, encrusting corallines are important framework builders. At Site-P, they had a higher coverage than at Site-T, where they occur in small patches (one to a few $\mathrm{cm}$ in diameter). According to Delgado \& Lapointe (1994), nutrient-enrichment was suggested to enhance productivity of encrusting corallines, but to a lower extent than that of fleshy algae. In the whole P coral zone, a significant increase in encrusting corallines coverage was observed between 1993 and 1996 (Fig. 2j), the coverage then remaining stable between 1996 and 2002. In fact, during the 1993 survey, corallines did coexist with macroalgae: they were living below the dense macroalgal "canopy" dominated by brown algae, and thus not taken into account by LITs. In 1996 and 2002, the decline of macroalgae led naturally to an increase of encrusting coralline coverage (and also of the encrusting Lobophora variegata coverage). An inverse relationship between corallines and fleshy macroalgae occurred, and may have been augmented by macroalgal-trapped sediments smothering the corallines (Steneck, 1997). As recorded by Littler and Littler (2006), encrusting corallines often predominate by default.

At Site-P, the regression of macroalgae, that occurred in 1995, may also have led to a better feedback control on the macroalgal standing crop by herbivore fish (as 
sea urchins were and are still absent in 2011) (Hatcher \& Larkum, 1983; Steneck, 1988 ) and thus, to an increase of encrusting coralline coverage. Controlled experiments with limpets in St-Croix, following Diadema antillarum mass mortality in Caribbean, suggest also that corallines require herbivores to remove fouling filamentous epiphytes (Steneck, 1997). Similarly, Chazottes et al. (2002) showed a significant negative correlation between grazing activity and encrusting coralline coverage on the Saint-Gilles La Saline reef. Accordingly, the ecological role of encrusting corallines cannot be separated from the influence of fleshy macroalgae, herbivores and productivity gradients (Littler \& Littler, 2006).

Moreover, ambient hydrodynamic conditions also influence the degree of competition between encrusting corallines and fleshy algae. In 1985-1990, at Site-P, every year, when strong trade-wind-generated swells broke over the reef front, most of the fleshy algae were torn off and carried away. As a result, encrusting corallines had 6 months of respite before suffering the next macroalgal overgrowth (Naim, 1993).

\section{Macroalgae}

Abundance. The abundance of macroalgae is considered to be a key measure of reef health (Steneck \& Sala, 2005). However, in Hawaii, Vermeij et al. (2010) proposed that high turf abundance is a better indicator of reef decline than high macroalgal abundance because turf abundance is the highest on reefs with low coral cover and few fish. This emphasizes that changes in community composition are context-dependent and that not all degraded reefs look the same.

At Site-P, in 1993, the dominance of macroalgae on the substratum, especially of the brown algae Padina spp, Dictyota spp., Turbinaria ornata, and the red alga, Gracilaria canaliculata, related to a reef flat in poor health and high nutrient levels (Cuet et al., 1988). In 1995, brown algae biomass regressed and in 2002, during survey 1 , macroalgae species appeared mostly intimately mixed together. Therefore, it can be affirmed that diversity in macroalgae (not measurable with LIT) has increased. The decline in macroalgal coverage (except for the encrusting Lobophora variegata), and the increase in turf coverage, in 1996 and 2002 are correlated with a better health of massive corals and a significant increase in their coverage (Tourrand et al., 2013).

Macroalgal biomass. In the 1993-94 hot season (February), in outer coral zones TN and PN, biomass was ten times higher at PN. At TN, only one species, Hydroclathrus clathratus, occurred in large amounts. This brown alga is known to outbreak during the boreal spring and to disappear quickly, as observed here in survey 4, but also in Eilat, Red Sea (Benayahu \& Loya, 1977) and in Moorea, French Polynesia (Payri \& Naim, 1982). In the PN subzone, most of the substrate was occupied, almost throughout the year, by macroalgae assemblages, that underwent changes in composition over time.

In back reef areas $\mathrm{TB}$ and $\mathrm{PB}$, the same trends as in the outer coral zones were observed, although displaying a lower biomass. The $\mathrm{T}$ back reef was typified by inconspicuous macroalgal populations, except in February (in the mid-rainy season), while the $\mathrm{P}$ back reef was invaded with Hypnea valentiae during the rainy season and Turbinaria ornata on hard substrates during the April-May period, both highly covered by epiphytes. 
The PN outer coral zone appeared the more favourable zone for primary producers, as their abundance, species richness and biomass was the highest across the studied reef flat system. In 1993-94, the PN macroalgal biomass measured in survey 4 was comparable with the biomass measured in Kaneohe Bay, in the worst affected area (sector CE; Smith et al., 1981; Semple, 1997) (Table 6). Over the last 22 years, the PN subzone remained one of the most degraded zone at Site-P and on the Saint-Gilles la Saline reef flat.

The case of Gracilaria canaliculata (formerly named G. crassa), Hypnea valentiae, Lobophora variegata and Turbinaria ornata

The 1985-1990 record. Among macroalgae recorded here, emphasis has to be given to Gracilaria canaliculata. From 1985 to 1990, during summer times, on reef flats from both Reunion and nearby Mauritius Island, Gracilaria canaliculata was observed to be invasive in areas subjected to freshwater inputs and high nutrientenrichment (Cuet, Naim, unpublished).

As far as we know, on the three sites of La Saline reef, labelled "Planch'Alizés" (Site-P), "Club Med", and at "south of the Hermitage pass" (see Fig.1, Tourrand et al., 2013), macroalgae were extremely abundant (Naim, 1993 and unpublished). In 1980's, in summer, perennial Gracilaria canaliculata populations were observed overgrowing and as a result, killing living coral colonies at Site-P and Site-Club Med (Photograph 1). At Site "South of the Ermitage pass", where coral degradation, the solid and rubbery thalli of $G$. canaliculata were devastating, wrapping and smothering living coral strips, of a meter or so, over one single month. A similar event was previously described in Kaneohe Bay, Hawaii, during the 1960's, but here the invasive species implicated was Dictyosphaeria cavernosa (Banner, 1974; Smith et al., 1981); Banner also reported a dense growth of Gracilaria sp., related to sewage pollution.

The successful development of Gracilaria canaliculata can be then explained by its rapid growth rate, its grazer resistance, its seasonal persistence, and its dispersal capacity, as observed in situ in nutrient-enriched MAS communities at Reunion and Mauritius (Cuet, Naim, non published). Studying the $\partial^{15} \mathrm{~N}$ ratio variability in tissues of the sponge Cliona inconstans and those of three coral species present in ACR (Site-T) and MAS (Site-Club Med), Risk et al. (1989), showed that the $\partial^{15} \mathrm{~N}$ signal at Site-Club Med was close to that of human urine, revealing then that sewage impacted the reef flat. The G. canaliculata growth rate can be explained by a rapid exploitation of nutrient pulse: Nelson (1985) demonstrated that photosynthesis of G. canaliculata is immediately enhanced by exposure to concentrations of dissolved ammonia up to $10 \mu \mathrm{M}$. The alga has also the ability to store nitrogen after nutrient pulses (Ryther et al., 1981; Bird et al., 1982). Moreover, at Site-P and Site-Club Med, when most of macroalgae are swept off by heavy swells in April, the thalli of living G. canaliculata remained trapped between living branching corals and/or massive coral cavities. Hidden in holes or protected by branches during winter, G. canaliculata also escaped grazing by large herbivores, such as the Naso fish, that can be locally abundant in MAS communities.

Considering now the status of Lobophora variegata in the 1980's at Site-P, in the $\mathrm{L}$ and $\mathrm{N}$ coral subzones, it occurred in crusts and blades, housed under the fronds of macroalgae, but blades only overgrew the bases and/or hollows of living corals. On the same reef, according to Chazottes et al. (2002), there was an inverse correlation 
between pressure of sea urchin grazing and Lobophora variegata coverage. In the Caribbean, this alga has a widespread distribution and, due to its creeping growth form, is considered to be particularly aggressive towards corals (Nugues \& Bak, 2006).

Considering now the status of Hypnea valentiae in the back reef areas of SiteP and Site-Club Med during summer in the 1980's, it appeared that its continuous mats were heavily epiphytized by Cyanophytes, turfs and and other macroalgae, and therefore often extended to $0.5 \mathrm{~m}$ in height above the sand bottom. The filamentous thalli of Hypnea valentiae were then overgrowing small living corals of c. $20-40 \mathrm{~cm}$ large, usually Porites (P.) lutea and Millepora exaesa, sparing larger coral colonies (Montipora circumvallata and $P$ (Synaraea) rus) but also limitating coral recolonization. However, $H$. valentiae was ephemeral and carried away by the tradewind swells. It therefore released corals in winter and left the resistant ones only partly damaged.

Every spring, when Galaxaura developed in association with Hypnea, the algal assemblage hosted numerous sea hares $(1-10 \mathrm{~cm})$, eating the Galaxaura calcareous filaments. From 1990 onwards, these sea hares have never been observed within the Hypnea/Galaxaura thalli. In 1990's, such an outbreak of Aplysia was also observed at the outfall of the turtle farm (Saint-Leu) $(\mathrm{c} . \leq 20 \mathrm{~cm}-$ Dolabella auricularia).

The shift in macroalgae dominance. Since the beginning of the 1990's, following the settlement of the sewage plant system along the western coast of Reunion, groundwater apparently contributed moderately to the reef nutrient budget (Cuet et al., 2006). Thus, at Site-P, the drastic decrease in macroalgae coverage can be referred to a "phase shift" due to a lower nutrient availability and better ambient conditions for corals.

Between 1993 and 1996, the Gracilaria canaliculata biomass dropped and from 1995, thalli of G. canaliculata virtually disappeared from the Sites "Planch' Alizés" and "Club Med" (Photograph 2). At the scale of the Saint-Gilles La Saline reef, some thalli (c. $10 \mathrm{~cm}$ large) of this alga were only observed close to some ravines (e.g. "south Ermitage pass", "north Trois Bassins pass").

Similarly, in summer 1995, coverage and biomass of $H$. valentiae occurred only in patches a centimeter or so in height. Benefiting from the demise of macroalgae, the Lobophora variegata coverage increased "by default" from 1996 although blades strongly decreased in number and no longer colonized the bases of living corals as observed in 1980's.

Likewise, Turbinaria ornata that was invading the subtidal substrates, strongly decreased from 1995. By contrast, throughout French Polynesia, Payri and Stiger (2001) reported that the range of Turbinaria ornata increased markedly since the 1980's to become invasive, on some Tahiti and Moorea reef flats (Andrefouët $e t$ al., 2004).

Nevertheless, although macroalgae are reported to increase in many areas, Bruno et al.'s review (2009) indicated that the replacement of corals by macroalgae as the dominant functional group is less common and less geographically extensive than generally assumed. 


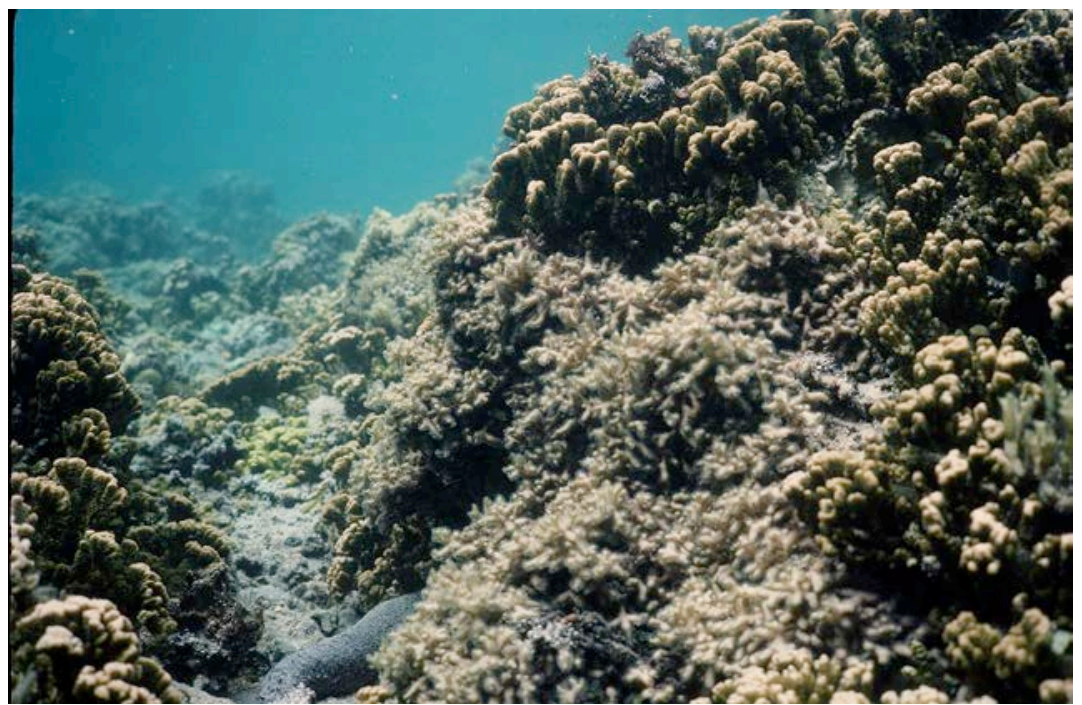

Photograph 1. 1987, Planch'Alizés (Site-P), L-zone. Large strip of Montipora circumvallata shrouded by the red alga, Gracilaria canaliculata (photography: O. Naim).

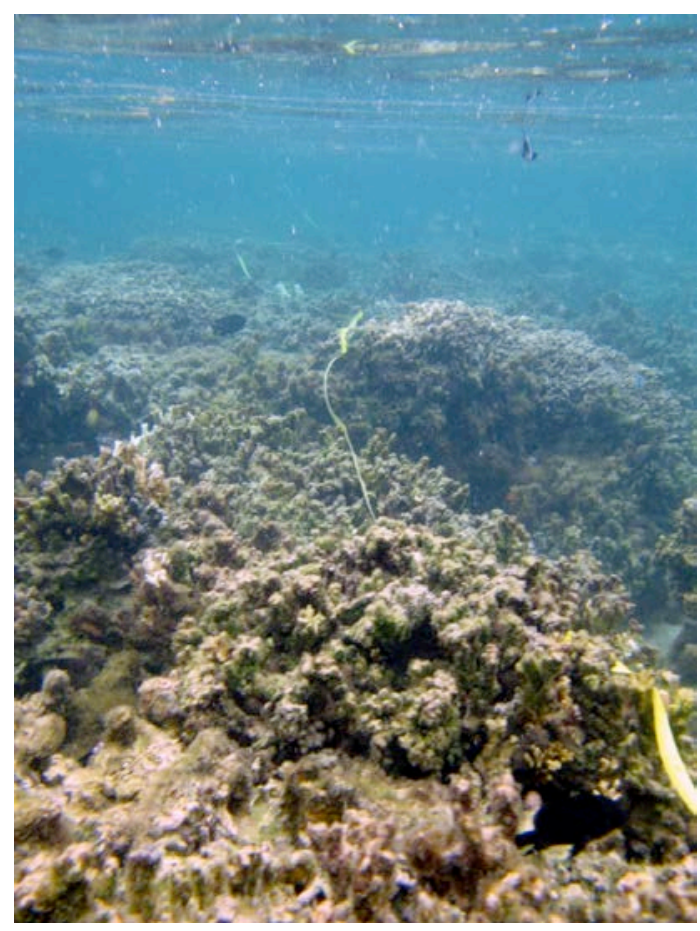

Photograph 2. 2009, Planch'Alizés (Site-P), L-zone. Large strip of the still dominant Montipora circumvallata (Naim et al., 2013). Macroalgae are rare, except Turbinaria ornata occurring on upper subtidal dead substrates in April-May (photography: B. Cauvin).

Species richness

Comparison of species richness in the Mascarenes. In Reunion, in her exhaustive study of algae (excluding Cyanophytes), Payri (1985) recorded 156 species of which 146 species occurred on coral reefs, and 87 living on the SaintGilles La Saline reef flat. In Mauritius, Jagtap (1993) recorded 127 species on 18 sites (Table 5). 
Table 5: Comparison of species richness in different studies

\begin{tabular}{ccccccc}
\hline & \multicolumn{3}{c}{ This paper (survey 3) } & Payri (1985) & Jagtap (1993) \\
& $\mathrm{T}$ & $\mathrm{P}$ & $\mathrm{T}+\mathrm{P}$ & St-Gilles la Saline Reef & Mauritius (18 sites) \\
\hline Cyanophyta & 4 & 4 & 4 & unknown & 5 \\
Chlorophyta & 14 & 24 & 26 & 36 & 34 \\
Ochrophyta(Phaeophyceae) & 8 & 8 & 8 & 13 & 20 \\
Rhodophyta & 26 & 31 & 36 & 38 & 68 \\
\hline TOTAL & 52 & 67 & 76 & 87 & 127 \\
\hline
\end{tabular}

In this paper (survey 3), 76 species were recorded on Site-T and Site-P, from only 6 stations $50 \mathrm{~m} \times 2 \mathrm{~m}$, indicating that almost $85 \%$ of the species were found compared to the Payri's inventory. In the survey, Caulerpa was only observed on both sites (8 species and subspecies present on the reef) but not recorded on LITs. Similarly, Halimeda, a dominant genus in the Indo-Pacific, was not recorded at either Site-T or Site-P, as the genus occurs rarely on Reunion reef flats, except on narrow reef flats and platforms (exposed conditions).

Despite an abundance 10 times higher at Site-P (LITs), the species richness and diversity appears to be similar at both sites when measured at higher resolution (infracentimetric). However, this diversity is calculated from the occurrence of species in the quadrats and not from their respective abundance. This finding seems consistent with the fact that there was roughly the same pool of species at both sites, with abiotic conditions (low/high nutrient concentrations), biotic (high/ low sea urchin or fish grazing) and metabolic conditions (autotrophy/ heterotrophy) shaping each algal community.

Different results from different methods. Algal dominance depends greatly on the sampling method. In PL subzone for example, the measurements in study 1, using the LITs method ( $\geq 1 \mathrm{~cm}$ level) and those in study 3 , based on a higher (infracentimetric) resolution, were performed at exactly the same location (permanent transect), but the LITs approach showed that beds of large brown algae dominated while the second approach showed that two Cyanophyta, Lyngbya majuscula and Blennothrix cantharidosma, and two Melobesiae were the dominant species. These four species mostly occurred in patches of less than $1 \mathrm{~cm}$ in width and thus, were largely underestimated by the LIT method. Similarly, in the TL and TN subzones, Hydrolithon onkodes and Lobophora variegata occurred in very small patches (of less than $1 \mathrm{~cm}$ in width) as a result of heavy grazing. Both species were underrepresented by LITs, although they were dominant at the infracentimetric level. In the same way, at Site-P, among Cyanophytes, mats of Lyngbya majuscula located in corals were hardly measured by LIT, while flat mats of Schizothrix calcicola were more readily quantified.

LITs measurements showed two different algal communities occurring at Sites $\mathrm{T}$ and $\mathrm{P}$, in relation to both abundance and composition of species. By contrast, the results based on the higher resolution approach showed that the algal community is best explained by reef physiography than by ecological differences between Sites $\mathrm{T}$ and $\mathrm{P}$.

Now, in order to increase the efficiency of monitoring, photographic and video methods are frequently used: the Coral Point Count with Excel extensions (CPCe) 
(Kohler \& Gill, 2006) appears to be the future of the "infracentimetric approach of the reef", all organisms included. It has been used in Reunion to estimate the initial state in the Marine Reserve (Bruggemann et al., 2007). Nevertheless, despite its great interest, this method remains time-consuming and thus, cannot be used for analyzing large areas: it therefore is one of the best complementary methods to the LIT-one.

Herbivory, nutrients and the benthic primary producer community

Herbivory. Structure, species diversity and biomass of algal communities are known to be controlled by herbivorous organisms (Ogden \& Lobel, 1978; Hay et al., 1983; Lewis and Wainwright, 1985; Lewis, 1986) and reduction of grazing by herbivores is known to unbalance the community (McCook, 1999). In 1983-1984, in the Caribbean, immediately following the mass mortality of Diadema antillarum, algal biomass increased on reefs where the sea urchin was dominant. The scientists who witnessed the die-off throughout the Caribbean have provided a data-rich literature on the immediate and longer-term response of algae (Lessios, 1988, review). Despite the increase in abundance and grazing by herbivorous fishes on reefs where D.antillarum died, the algal community continued to increase in coverage and biomass, indicating that grazing by fish did not compensate for the loss of grazing by the sea-urchin in controlling algal abundance (Carpenter, 1990). In Hawaii, Jones (1968) noted that, despite 160 genera of algae available to Acanthuridae (herbivorous fish), only $20 \%$ were found in the fish stomachs, suggesting that many algae may be unpalatable or repellent. Moreover, Littler and Littler (1985) thought that herbivory exerted much more control over the relative dominance of coral and algae than do nutrient levels, and Steneck (1988) showed that macroalgal assemblages can only sustain themselves with reduced pressure of herbivory. In Kaneohe Bay, following the diversion of most of the sewage effluent in 1977-1978, it was expected that $D$. cavernosa growth would become nutrient-limited and its abundance would consequently decline, but the alga remained abundant. Stimson et al. (2001), by measuring the grazing intensity and by surveys of herbivorous fish abundance, suggested that the continued abundance of $D$. cavernosa was, in part, the result of a reduction in grazing intensity.

At Site-T, the primary producer coverage remained below $10 \%$ while the density of sea urchins increased significantly from 40 ind. per $10 \mathrm{~m}^{2}$ in 1993 to 90 ind. per $10 \mathrm{~m}^{2}$ in 2002 (Tourrand et al., 2013). At Site-P, sea urchins were rare in the back reef $\left(<1\right.$ ind. per $\left.10 \mathrm{~m}^{2}\right)$, and totally absent in the coral zone. At both sites, Echinometra mathaei was and still is the dominant sea urchin (Tourrand et al., 2013). Tripneustes gratilla was locally present (Semple, 1997; Lison de Loma et al., 2002). Diadematidae were and still are rare (in 2013) at Site-T (except Echinothrix diadema on the reef front and the upper spur and groove section, not studied here) and were and still are (in 2013) totally absent at Site-P. As herbivorous fish are numerous on both sites (Letourneur, 1992; Chabanet, 1994, Table 6), the high biomass of soft macroalgae outcompeting living corals in the 1980's at Site-P can be attributed in part to echinoid undergrazing. Yet, from 1993 to 2002, at Site-P, the primary producer coverage decreased but the echinoid density did not change. This may indicate that nutrient availability for algae decreased through these ten years.

Although Sammarco (1982) considered sea urchin grazing to be one of the structuring forces in coral reefs, algal blooms are also particularly pronounced on reefs that have low stocks of herbivorous fish (Lessios, 1988). Comparing species of 
fish at Sites T and P, Chabanet et al. (1997) showed that, among Acanthuridae, the unicorn tang, Naso unicornis, was more abundant at Site-P while Ctenochaetus striatus and Zebrasoma scopas were more abundant at Site-T. In the 1980's, Naso unicornis, which are constant feeders, were very active at dawn, as schools of about ten individuals on the $\mathrm{P}$ coral zone and were observed particularly feeding on Gracilaria caniculata thalli (Naim, pers. obs.). On the Great Barrier Reef, Hoey and Bellwood (2011) found that the grazers, in contrast to the browsers (like Naso unicornis), consistently stayed away from the patches with high macroalgal density. The authors hypothesise that the grazers could avoid the dense macroalgae patches because of a higher density of predators within or because the large algal stands are simply more unpalatable.

Nutrient loading at both sites. Smith et al. (1981) in Kaneohe Bay and Lapointe et al. (1997) in Florida showed that large shifts in community structure may occur as a result of nutrient loading. In 1996, Mioche (1998) showed that ACR communities had an autotrophic functioning at the inflow sites, "Toboggan" (Site-T) and "Petit Trou d'eau", while MAS community had a heterotrophic regime at the outflow sites, "Planch'Alizés" (Site-P), and "Club Med" (Mioche et al., 2002). Mioche \& Cuet (2002) regarded then MAS as an altered stage of ACR in a nutrientenriched environment. The increase of biomass of primary producers, especially of macroalgae, as well as productivity, may negatively impact stenoecious organisms, such as Acropora as well as the sea urchins, Echinometra mathaei and the Diadematidae, Diadema spp and Echinothrix diadema, by exposing them to elevated respiration rates, these genera and/or species being rare or completely absent in MAS (Semple, 1997; Tourrand et al., 2013). Table 6 gives the dominant facies at both sites in the 1980's, when the primary producers were the lowest at Site-T and the highest at Site-P.

Table 6. The 1985-1990 period: some differences in ACR and MAS community structures (primary producers, metabolism, nutrients, and herbivory pressure) during the hot season.

\begin{tabular}{|c|c|c|}
\hline & ACR community (Site-T) & MAS community (Site-P) \\
\hline $\begin{array}{l}\text { Primary } \\
\text { producers }\end{array}$ & Inconspicuous coverage & $80 \%$ of the coverage. \\
\hline Cyanophytes & $\begin{array}{l}\text { They occur in small blooms, } \\
\text { no perennial species. }\end{array}$ & $\begin{array}{l}\text { They occur in large blooms and can be } \\
\text { invasive during summer (Schizothrix } \\
\text { calcicola). Some of them, such as } \\
\text { Lyngbya majuscula, are perennial. }\end{array}$ \\
\hline Turfs & Dominant & Dominant with macroalgae \\
\hline $\begin{array}{l}\text { Encrusting } \\
\text { corallines }\end{array}$ & $\begin{array}{c}\text { They occur in c. } 1 \mathrm{~cm} \text { large patches (heavily } \\
\text { grazed). }\end{array}$ & $\begin{array}{l}\text { In back reef, digitated ones encrust dead } \\
\text { substrates and rubble (forming rhodoliths). } \\
\text { In the coral zone, encrusting forms expand } \\
\text { as large patches over subtidal dead } \\
\text { substrates, and are often hidden by } \\
\text { macroalgae. } \\
\text { Digitated ones are abundant on dead coral } \\
\text { walls. }\end{array}$ \\
\hline \multirow[t]{2}{*}{ Macroalgae } & $\begin{array}{l}\text { Inconspicuous except a few species that } \\
\text { occur in large and ephemeral blooms } \\
\text { (Hydroclathrus clathratus, Boodlea } \\
\text { composita). } \\
\text { Abundant encrusting Lobophora variegata } \\
\text { occurs in c. } 1 \mathrm{~cm} \text { large patches. }\end{array}$ & $\begin{array}{l}\text { Numbered species form pluridecimetric } \\
\text { mats (Dictyota spp, Gracilaria } \\
\text { canaliculata (= G. crassa), Padina spp, } \\
\text { Turbinaria ornata). Gracilaria } \\
\text { canaliculata is perennial. Lobophora } \\
\text { variegata forms large crusts with blades. }\end{array}$ \\
\hline & Biomass, TN: max. dry weight: 38 g.m ${ }^{-2}$ & Biomass, PN: max. dry weight: 267 g.m $\mathrm{m}^{-2}$ \\
\hline
\end{tabular}




\begin{tabular}{|c|c|c|}
\hline & & $\begin{array}{l}\text { (in Kaneohe Bay, sector CE -the worst: } \\
\text { max. dry weight } 292 \text { g.m } \mathrm{m}^{-2} \text {, } \\
\text { Smith } \text { et al.. } 1981 \text { ) }\end{array}$ \\
\hline \multirow[t]{2}{*}{ Metabolism } & Oligotrophic & Heterotrophic \\
\hline & (Mioche, 1998) & ( Mioche, 1998) \\
\hline \multirow{2}{*}{$\begin{array}{l}\text { Silicium } \\
\left(\mathrm{SiO}_{2}\right)\end{array}$} & at low tide & at low tide \\
\hline & $\begin{array}{l}\mathrm{SiO}_{2}<5 \mu \mathrm{M} \\
\text { (Cuet, } 1989 \mathrm{~b} \text { ) }\end{array}$ & $\begin{array}{c}10 \mu \mathrm{M}<\mathrm{SiO}_{2}<50 \mu \mathrm{M} \\
\text { (Cuet, 1989b) }\end{array}$ \\
\hline \multirow{3}{*}{$\begin{array}{c}\text { Nitrates } \\
\left(\mathrm{NO}_{3}^{-}\right)\end{array}$} & back reef water concentrations: & back reef water concentrations: \\
\hline & $\begin{array}{c}0.73 \pm 0.62 \mu \mathrm{M}) \\
\text { (Cuet, } 1989 \mathrm{~b})\end{array}$ & $\begin{array}{c}3.23 \pm 1.93 \mu \mathrm{M} \\
\text { (Cuet, } 1989 \mathrm{~b})\end{array}$ \\
\hline & $\begin{array}{l}\text { threshold below } 1.3 \mu \mathrm{M} \mathrm{NO}_{3}^{-} \\
\quad \text { (Naim \& Cuet, 2002) }\end{array}$ & $\begin{array}{l}\text { threshold higher than } 3.5 \mu \mathrm{M} \mathrm{NO}_{3}^{-} \\
\text {(Naim \& Cuet, 2002) }\end{array}$ \\
\hline \multirow{4}{*}{$\begin{array}{l}\mathrm{C}: \mathrm{N} \text { in back } \\
\text { reef } \\
\text { sediment } \\
\text { Sea urchins } \\
\text { Herbivorous } \\
\text { fish }\end{array}$} & $\begin{array}{l}\mathrm{C}: \mathrm{N}: 3.7 \pm 0.5 \text { and } 7.5 \pm 1.0 \\
\quad \text { (Kolasinski et al., } 2011) \\
\quad \text { (Site-Petit trou d'eau) }\end{array}$ & $\begin{array}{l}\mathrm{C}: \mathrm{N}: 11.7 \pm 3.8 \text { and } 15.6 \pm 2.5 \\
\quad \text { (Kolasinski } \text { et al., } 2011 \text { ) }\end{array}$ \\
\hline & Very abundant (> 40 ind. per $10 \mathrm{~m} 2)$ & Almost absent $(<1$ ind. per $10 \mathrm{~m} 2)$ \\
\hline & summer: $13.5 \pm 2.2$ herbivores per $100 \mathrm{~m}^{2}$ & summer: $14.1 \pm 2.2$ herbivores \\
\hline & (Letourneur, 1992) & 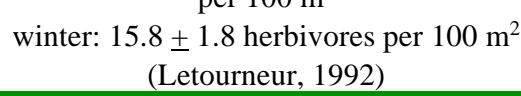 \\
\hline
\end{tabular}

The nutrient-threshold hypothesis (Bell, 1992; Lapointe, 1997) predicts that coral reefs will experience macroalgal blooms at nutrient concentrations above a threshold level of 1.0 M dissolved inorganic nitrogen (DIN).

At Saint-Gilles La Saline, in 1988, monthly water sampling of back reef waters during one year showed also that nitrate was significantly higher $(\mathrm{p}<0.0001)$ at Site-P than at Site-T (Cuet, 1989b, table 6). Moreover, water samples were taken in 1988 at low tide on the 9-km long Saint-Gilles La Saline reef at the end of the rainy season, and the reef communities were concomitantly analyzed by LITs and classified as "pure" ACR, "pure" MAS or intermediary (cartography of samples is in Cuet et al., 1988 and Naim 2006). Naim \& Cuet (2002) showed then that, in the backreef zone, in a silicate-nitrate diagram, all the "pure" ACR-LITs registered below 1.3 $\mu \mathrm{M} \mathrm{NO}_{3}{ }^{-}$, and all the "pure" MAS-LITs registered above $3.5 \mu \mathrm{M} \mathrm{NO}_{3}{ }^{-}$. Therefore, the back-reef occurrence of ACR or MAS communities appeared to be correlated with the $\mathrm{NO}_{3}{ }^{-}$concentrations. No such clear relationship could be demonstrated in the coral zone, nor in a silicate-phosphorus ordination.

Therefore, in Reunion, «pure » ACR community appears to turn gradually into «pure » MAS community when $\mathrm{NO}_{3}{ }^{-}$concentration increases from 1 to $3 \mu \mathrm{M}$ in the back reef, and the threshold of $1.3 \mu \mathrm{M}$ per litre of nitrate for healthy communities is roughly the same as that suggested by Bell (1992) and Lapointe (1997).

More recently, in August 2006 and March 2007 respectively, Kolasinski et al. (2011) showed that, on Site-P, back reef and inner coral zone are characterized by a very high contribution of benthic detritus. This was particularly evident on the back reef where the sediment particulate organic matter (SOM) reservoir showed the most elevated C:N ratios analyzed on the La Saline reef (Table 6).

Site-T and site-P in the Relative Dominance Model (RDM, sensu Littler and Littler, 1984). There has been an exhaustive debate over the ecological factors regulating coral reef community structure (Littler et al., 2006, 2009 and many others). 
As argued by Hughes et al. (1999), a reef community cannot be structured only by the influence of nutrient-loading. The competition-based Relative Dominance Model (RDM) (Fig. 7 from Littler and Littler, 1984, 2006) is a comprehensive model predicting the dominant group of autotrophs in coral reef communities as a function of "top-down" regulation by herbivores and "bottom-up" control by nutrientavailability. Based on the Relative Dominance Model, the algal composition and the abundance of sea urchin (and thus, as part of the grazing pressure) recorded in both previous and ongoing studies, Site-T in 1987 (T1987, fig.7) can be thought to have experienced a low nutrient input, since it exhibits inconspicuous primary producers and a high sea-urchin grazing pressure (Tourrand et al., 2013). Similarly, Site-P in 1985 (P1985, fig.7), devoid of sea-urchins, is interpreted as having suffered a high nutrient level, since it was dominated by frondose macroalgae which were overgrowing living corals during the hot season. In 1993, as the macroalgal pressure decreased, and sea-urchins still were almost lacking, the nutrient-level is considered to have decreased. In 1995, the disappearance of Gracilaria caniculata clearly reflects improved environmental conditions, and in 2002, the strong regression of macroalgal cover signals an actual drop in nutrient concentration.

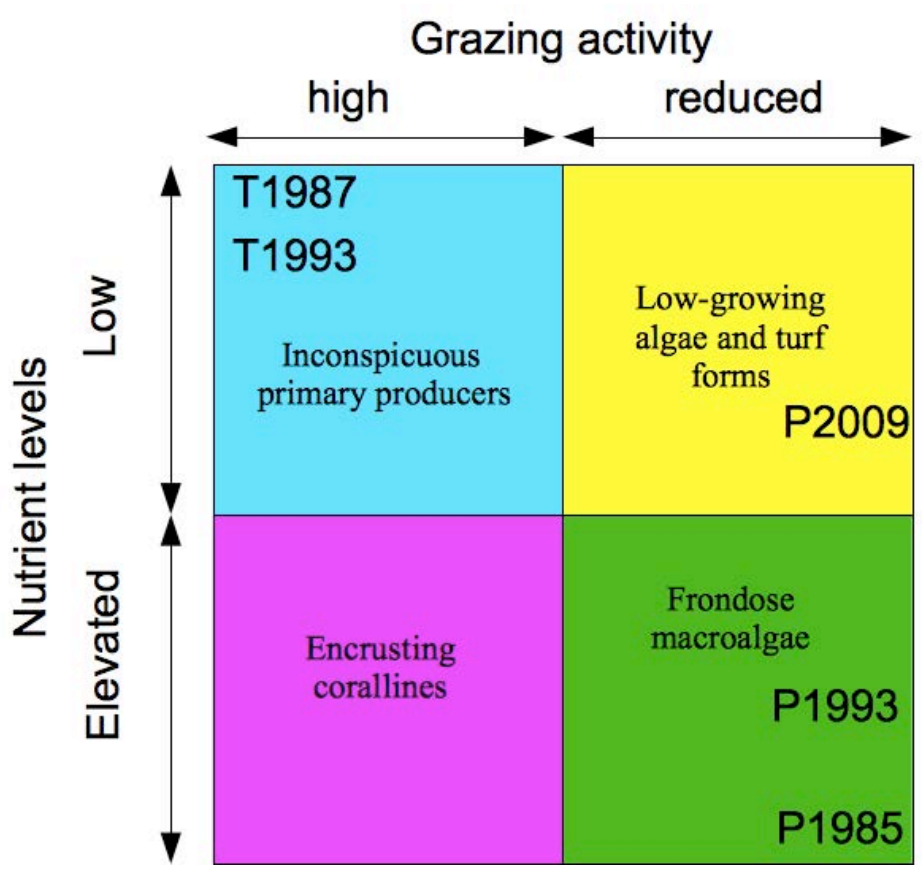

Figure 7: The competition-based Relative Dominance Model (RDM) modified from Littler and Littler (1984, 2006). T= Site-“Toboggan"; $\mathrm{P}=$ site-"Planch'Alizés ») years are given according to quantitative data recorded on the two sites.

Over the 2004-2009 period, the reef communities from both Sites T and P shifted to become turf-dominated with an increase of encrusting corallines at Site-P. At Site-T, the increase in turf density is not accompanied by an increase in encrusting coralline coverage. According to the RDM, it would not indicate a higher nutrientlevel, but can be much more related to an increasing stress of Acropora (bleaching events). At Site-P, by contrast, the shift from a state dominated by macroalgae (P1985 and P1993) to a state dominated by turfs (P2009) indicates that, according to the 
$\mathrm{RDM}$, the reef flat today experiences a lower nutrient level. As nutrient-enrichment is less evident presently (Cuet et al., 2006), further studies are conducted currently.

Interaction between abiotic and biotic factors. In summary, on the SaintGilles La Saline reef, compared to ACR at Site-T, MAS observed at Site-P, appears to be the result of a higher chronic variability of abiotic factors, such as a higher temperature (Denis et al., 2009), a lower salinity, a higher and variable silicate amount during low tides and a variable nutrient enrichment via submarine groundwater discharge (Table 6, Cuet, 1989b), an enrichment in organic matter of the reef waters as they flow across the subtidal communities (Conand et al., 2002; Kolasinski et al., 2011), a lack of dissolved oxygen at the end of the night (heterotrophy) (Mioche, 1998), and the occurrence of potential toxic elements (due notably to the abundance of the cyanophyte Lyngbya majuscula). Similarly, biotic factors may control in part the composition of MAS. These factors include undergrazing by sea urchins, avoidance of unpalatable macroalgae by herbivorous fish and intense competition between living corals and a variety of algae. In 1980's, the algal competitors included either Cyanophytes, turfs, soft macroalgae or encrusting corallines (Naim, 1993), while Cyanophytes and turfs operate today. In addition, the fish Stegastes nigricans acts as a control from enriching more significantly its immediate environment at Site-P than at Site-T (Lison de Loma, 2000). All factors interact in an extremely complex way.

Intimate coexistence between living corals and primary producers. MAS is also a community where massive corals and primary producers coexist from 1980's. From 1987 to 2009, the primary producer and the massive living coral coverages never dropped below 40\% and 30\% respectively (Tourrand et al., 2013, fig. 5, PL-subzone, average, summer data). This coexistence, especially when macroalgae were overgrowing corals in 1980's, may be explained by the "breathing" of corals during the dry season (from April to November), when the algae are washed away by powerful swells (Naim, 1993) and the freshwater inflows are reduced (Cuet, 1989b). Thus, MAS appears to be also the result of a seasonal alternation, a hot season where algae are taking over, and a cold season where corals can recover. In this type of community, the seasonal rhythm requires further analysis than in a healthy coral community, due to the intimate competition between benthic primary producers and living corals.

\section{CONCLUSION}

In the 1970's, the reef flats in Reunion displayed flourishing branching corals. During the decade1980-90, Site-T retained its prosperous branching structure with inconspicuous primary producers while Site-P was altered by a phase shift leading to massive corals and macroalgae. This study showed that, between 1996 and 2002, another phase shift occurred at the two studied sites. Site-P has lost its frondose macroalgae while Site-T lost its «inconspicuous primary producer » state, and both $\mathrm{T}$ and $\mathrm{P}$ primary producer communities have shifted to a turf controlled community. As sea urchin herbivory has not greatly changed at either site, «bottom-up control» via nutrient enrichment may be one of the suspected causal factors. The sewage treatment may be responsible for the macroalgae disappearance at Site-P, and the diversion of water from east to west in Reunion leads to the accumulation of freshwater on the Ermitage watershed, and this may be one of the factors resulting in degradation at Site-T. In 2007, the creation of the Marine Reserve, which placed the T-coral zone 
into the sanctuary, may allow a better understanding of the functioning of this process.

\section{ACKNOWLEDGMENTS}

We thank M. Daniel CHOUSSY for his assistance during fieldwork. We also thank Pr Terence J. DONE for rereading this paper. This project was funded by the « programme quadriennal laboratoire ECOMAR, université de la Reunion, Région Reunion » and the « Ministère de l'Enseignement Supérieur et de la Recherche (MESR)».

\section{REFERENCES}

Andrefouët, S., M. Zubia and C.E. Payri

2004. Mapping and biomass estimation of the invasive brown algae Turbinaria ornata (Turner) J. Agardh and Sargassum mangarevense (Grunow) Setchell on heterogeneous Tahitian coral reefs using 4-meter IKONOS satellite data. Coral reefs 23: 26-38.

Banner, A.H.

1974. Kaneohe Bay, Hawaii: urban pollution and a coral reef ecosystem. Proceedings of the $2^{\text {nd }}$ International Coral Reef Symposium, Brisbane, Australia 2: 685-702.

Baravetza, M.A. and A.W.D. Larkum

1986. Reef algae. Oceanus 29: 49-54.

Bell, P.R.F.

1992. Eutrophication and coral reefs: some examples in the Great Barrier reef lagoon. Water research 26: 553-558.

Benayahu, Y. and Y. Loya

1977. Seasonal occurrence of benthic algae communities and grazing regulation by sea urchins at the coral reefs of Eilat, Red Sea. Proceedings of the $3^{\text {rd }}$ International Coral Reef Symposium, Miami, Florida 1: 383-389.

Berner, $\mathrm{T}$.

1990. Coral reef algae. In: Ecosystems of the world 25 (Dubinsky, Z. ed.): Pp. 253-263.

Bird, K.T., C. Habig and T. De Busk

1982. Nitrogen allocation and storage patterns in Gracilaria tikvahiae (Rhodophyta). Journal of Phycology 18: 344-348.

Bruno, J.F., H. Sweatman, W.F. Precht, E.R. Selig and V.G.W. Schutte

2009. Assessing evidence of phase shifts from coral to macroalgal dominance on coral reefs. Ecology 90(6): 1478-1484.

Burris, R.H.

1976. Nitrogen fixation by blue-green algae of the Lizard Island area of the Great Barrier Reef. Australian Journal of Plant Physiology 3: 41-51.

Carpenter, R.

1990. Mass mortality of Diadema antillarum II. Effects on population densities and grazing intensity of parrotfishes and surgeonfishes. Marine Biology 104: 79-86.

Chabanet, P.

1994. Étude des relations entre les peuplements coralliens et les peuplements ichtyologiques sur le complexe récifal de Saint-Gilles La Saline. Doct. spéc. Environnement marin, Univ. AixMarseille III., France, 200 pp.

Chabanet, P., V. Dufour and R. Galzin

1995. Disturbance impact on reef fish communities in Reunion Island (Indian Ocean). Journal of Experimental Marine Biology and Ecology, 188 : 29-48.

Chazottes, V., T. Le Campion-Alsumard, M. Peyrot-Clausade and P. Cuet

2002. The effects of eutrophication-related alterations to coral reef communities on agents and rates of bioerosion. Coral reefs, 21: 375-390. 
Clarke, K.R. and R.M. Warwick

2001. Change in marine communities: an approach to statistical analysis and interpretation. $2^{\text {nd }}$ edn, PRIMER-E Ltd, Plymouth.

Conand, C., P. Cuet, O. Naim and D. Mioche

2002. Des coraux sous surveillance. Pour la Science, 298: 75-81.

Cuet, $\mathrm{P}$.

1989a. Les platiers récifaux de l'île de la Réunion. Physico-chimie des eaux. Rapport Univ. Réunion (Lab.Ecol.Mar) - Agence Urbanisme Réunion, 151 pp.

1989b. Influence des résurgences d'eau douce sur les caractéristiques physico-chimiques et métaboliques de l'écosystème récifal à La Réunion. Doctorat de spécialité en Environnement marin, Univ. Aix-Marseille III, France, 204 pp.

Cuet, P., O. Naim, G.F. Faure and J.-Y. Conan

1988. Nutrient-rich groundwater impact on benthic communities of la Saline fringing reef (Reunion Island, Indian Ocean): preliminary results. Proceedings of the $6^{\text {th }}$ International Coral reef Symposium, Townsville, Australia 2: 207-212.

Cuet, P., J. Turquet and J.F. Chiffoleau

2006. Phase pilote d'extension du RNO à la Réunion. Résultats des trois années de suivi (20022005). Rapport Université de la Réunion, ARVAM, IFREMER, DIREN Réunion, 93 pp.

Delgado, O and B. E. Lapointe

1994. Nutrient-limited productivity of calcareous versus fleshy macroalgae in a eutrophic, carbonate-rich tropical marine environment. Coral Reefs 13:151-159.

Denis, V., S. De Palmas, J. Debreuil, H. Bruggemann and M.M.M. Guillaume

2009. Resisting climate change: phenotypic plasticity and environemantal imprints in Acropora muricata from Reunion island. Proceedings of the $6^{\text {th }}$ Western Indian Ocean Marine Science Association (WIOMSA) Scientific Symposium, St-Denis, La Réunion, p. 89.

Hatcher, B.G. and A.W.D. Larkum

1983. An experimental analysis of factors controlling the standing crop of the epilithic algal community on a coral reef. Journal of Experimental Marine Biology and Ecology 69: 61-84.

Hay M.E., T. Colburn and D. Downing

1983. Spatial and temporal patterns of herbivory on a Caribbean fringing reef: The effects on plant distributions. Oecologia (Berlin) 58:299-308.

Hoey, A.S. and D.R. Bellwood

2011. Suppression of herbivory by macroalgal density: a critical feedback on coral reefs? Ecology Letters 14, pp. 267-273.

Hughes, T., A.M. Smant, R. Steneck, R. Carpenter and S. Miller

1999. Algal blooms in coral reefs: what are the causes? Limnology and Oceanography 44: 15831586.

Jagtap, T.G.

1993. Studies on littoral and sublittoral macrophytes around the Mauritius coast. Atoll Research Bulletin 382: 21 p.

Jones, R.S.

1968 Ecological relationships in Hawaiian and Johnston island Acanthuridae (Surgeonfishes). Micronesica 4: 369-371.

Kohler, K.E. and S.M. Gill

2006. Coral Point Count with Excel extensions (CPCe): a visual basic program for the determination of coral and substrate coverage using random point count methodology. Computers \& Geosciences 32: 1259-1269. http:// www.nova.edu/ocean/cpce/

Kolasinski, J., K. Rogers, P. Cuet, B. Barry and P. Frouin

2011. Sources of particulate organic matter at ecosystem scale: a stable isotope and trace element study in a coral reef (Reunion island, Indian Ocean). Marine Ecology Progress Series 443: 77-93.

Lapointe, B.E.

1997. Nutrient thresholds for bottom-up control of macro-algal blooms on coral reefs in Jamaica and southeast Florida. Limnology and Oceanography 42: 1119-1131. 
Lapointe B.E., M.M. Littler and D.S. Littler

1997. Macroalgal overgrowth of fringing coral reefs at Discovery Bay, Jamaica: bottom-up versus top-down control. Proceedings of the $8^{\text {th }}$ International Coral Reef Symposium, Smithsonian Tropical Research Institute, Panama 1: 927-932.

Lessios, H. A.

1988. Mass mortality of Diadema antillarum in the Caribbean: What have we learned? Annual Review of Ecological Systems 19: 371-393.

Letourneur, Y.

1992. Dynamique des peuplements ichtyologiques des platiers récifaux de l'île de la Réunion. Doctorat de Spécialité en Océanologie, Université Perpignan-Réunion, France, 244 pp.

Letourneur Y., M.L. Harmelin-Vivien and R. Galzin

1993. Impact of hurricane Firinga on fish community structure on fringing reefs of Reunion Island, S.W. Indian Ocean. Environmental Biology of Fishes 37: 109-120.

Lewis S.M.

1986. The role of herbivorous fishes in the organization of a Caribbean reef community. Ecological Monographs 56: 183-200.

Lewis S.M. and P.C. Wainwright

1985. Herbivore abundance and grazing intensity on a Caribbean coral reef. Journal of Experimental Marine Biology and Ecology 87: 215-228.

Lison de Loma, $\mathrm{T}$.

2000. Algal food processing by Stegastes nigricans, an herbivorous damselfish: differences between an undisturbed and a disturbed coral reef site (La Réunion, Indian Ocean). Oceanologica acta, 23 (7), 793-804.

Lison de Loma, T. and E. Ballesteros

2002. Microspatial variability inside epilithic algal communities within territories of the damselfish Stegastes nigricans at La Réunion (Indian Ocean). Botanica Marina 45 (4), 316323.

Lison de Loma, T., C. Conand, M.L. Harmelin-Vivien and E. Ballesteros

2002. Food selectivity of Tripneustes gratilla (L.) (Echinodermata: Echinoidea) in oligotrophic and nutrient-enriched coral reefs at La Reunion (Indian Ocean). Bulletin of Marine Sciences 70, 927-938.

Littler, M.M. and D.S. Littler

1984. Models of tropical reef biogenesis: the contribution of algae. In: Progress in Phycological Research (Round, F.E., Chapman, D.J., eds), Biopress, Bristol, vol. 3, pp. 323-364.

1985. Factors controlling relative dominance of primary producers on biotic reefs. Proceedings of the $5^{\text {th }}$ International Coral reef Symposium, Tahiti, Polynésie française, 4: 35-39.

2006. Assessment of coral reefs using herbivory/.nutrient assays and indicator groups of primary producers: a critical synthesis, proposed protocols and critique of management strategies. Aquatic Conservation: Marine and Freshwater ecosystems 17(2): 195-215.

Littler, M.M., D.S. Littler and B.L. Brooks

2006. Harmful algae on tropical reefs: bottom-up eutrophication and top-down herbivory. Harmful algae 5 (5): 565-585.

2009. Herbivory, nutrients, stochastic events, and relative dominances of benthic indicator groups on coral reefs: a review and recommendations. Smithsonian Contributions to the Marine Sciences 38: 401-414.

McCook, L.J.

1999. Macroalgae, nutrients and phase shifts on coral reefs: scientific issues and management consequences for the Great Barrier Reef. Coral Reefs 18: 357-367.

Miller, M.W., M.E. Hay, S.L. Miller, D. Malone, E.E. Sotka and A.M. Szmant

1999. Effects of nutrients versus herbivores on reef algae : a new method for manipulating nutrients on coral reefs. Limnology and Oceanography 44 (8) : 1847-1861.

Mioche, D. 
1998. Aspects du cycle de la matière sur les récifs frangeants de l'île de la Réunion (Océan Indien) : signature des dégradations et mécanismes de l'eutrophisation. Doctorat de Spécialité en Écologie marine, Université Réunion, 292pp.

Mioche, D. and P. Cuet

2002. Community metabolism on the reef flats at Reunion (Indian Ocean): natural versus anthropogenic disturbance. Proceedings of the $9^{\text {th }}$ International Coral reef Symposium, Bali, Indonesia 1: 431-436.

Mioche, D., R. Troadec, N. Germain, C. Esbelin, C. Tourrand, M. Psaradellis, O. Naim and J. Coudray

2002. Relations entre l'équilibre sédimentaire des plages, la structure des communautés et le budget des carbonates dans l'écosystème corallien de la Réunion. The Journal of Nature (Reunion), 14(1): 35-43.

Morrow, K.M., V.J. Paul, M.R. Liles and N.E. Chadwick

2011. Allelochemicals produced by Caribbean macroalgae. Coral reefs 30 (2): 309-320.

Naim, O.

1989. Les platiers récifaux de l'île de la Réunion. Géomorphologie et état de santé des peuplements benthiques. Rapport Université Réunion (Laboratoire d'Ecologie Marine) Agence Urbanisme Réunion, 151 pp.

1993. Seasonal responses of a fringing reef community to eutrophication (Reunion Island, Western Indian Ocean). Marine Ecology Progress Series 99: 307-315.

2006. The coral reef communities at Saint-Gilles La Saline in 1987 (Reunion Isl., S.W. Indian Ocean). The Journal of Nature (Reunion), 18(1): 13-31.

Naim, O. and P. Cuet

2002. Benthic community structure versus nitrate input at Reunion (SW Indian ocean). Proceedings of the $9^{\text {th }}$ International Coral reef Symposium, Bali, Indonesia, summary

Naim, O., C. Tourrand, G.F. Faure, L. Bigot, B. Cauvin, S. Semple and L.F. Montaggioni

2013. Fringing reefs of Reunion island and eutrophication effects. Part 3: Long-term monitoring of living corals. Atoll Research Bulletin, 598: 32 p.

Nelson, S.G.

1985. Immediate enhancement of photsynthesis by coral macrophytes in response to ammonia enrichment. Proceedings of the $5^{\text {th }}$ International Coral reef Symposium 5: 65-70.

Nugues, M.M. and R.P.M. Bak

2006. Differential competitive abilities between Caribbean coral species and a brown alga: a year of experiments and a long-term perspective. Marine Ecology Progress Series 315: 75-86.

Ogden, J.C. and P.S. Lobel

1978. The role of herbivorous fishes and urchins in coral reef communities. Environmental Biology of Fishes 3 (1): 49-63.

Payri, C.E.

1985. Contribution to the knowledge of the marine benthic flora of la Reunion island (Mascarene archipelago, Indian ocean). Proceedings of the $5^{\text {th }}$ International Coral reef Symposium, Tahiti, Polynésie française 6: 635-640.

Payri, C.E. and O. Naim

1982. Variations entre 1971 and 1980 de la biomasse et de la composition des populations de macroalgues sur le récif corallien de Tiahura (île de Moorea, Polynésie française). Cryptogamie: Algologie, III (3): 229-240.

Payri, C.E. and V. Stiger

2001. Macroalgal community changes on French Polynesian reefs, 1980-2000. Phycologia, 40 (4): 111.

Potts, M. and B.A. Whitton

1977. Nitrogen fixation by blue-green algal communities in the intertidal zone of the lagoon of Aldabra atoll. Oecologia 27: 275-283.

Risk, M., P.W. Sammarco, O. Naim and H. Schwarcz

1989. Stable isotopes of carbon and nitrogen in environmental studies on reefs: some preliminary results from Australia and Reunion. International Society for Reef Studies, annual meeting, Marseille, France, abstract 
Ryther, J.H., N. Corwin, T.A. De Busk and L.D. Williams

1981. Nitrogen uptake ans storage by the red alga Gracilaria tikvahiae (McLachlan 1979). Aquaculture 26: 107-115

Sammarco, P.W.

1982. Echinoid grazing as a structuring force in coral communities: whole reef manipulations. Journal of Experimental Marine Biology and Ecology 61: 31-55.

Semple, S.

1997. The use of temporal variations in algal cover and biomass as a tool for the quantification of the degree of eutrophication of a fringing coral reef in Reunion Island, S.W. Indian Ocean. Oceanologica Acta, 20 (6): 851-861.

Smith, S.V., W.J. Kimmerer, E.A. Laws, R.E. Brock and T.W. Walsh

1981. Kaneohe Bay sewage diversion experiment: perspectives on ecosystem responses to nutritional perturbation. Pacific Science 35 (4): 279-395.

Steneck, R.S.

1988. Herbivory on coral reefs: a synthesis. Proceedings of the $6^{\text {th }}$ International Coral reef Symposium, Townsville, Australia 1: 37-49.

1997. Crustose corallines, other algal functional groups, herbivores and sediments : complex intercations along reef productivity gradients. Proceedings of the $8^{\text {th }}$ International Coral reef Symposium, Smithsonian Tropical Research Institute, Panama 1: 695-700.

Steneck, R.S. and E.A. Sala

2005. Large marine carnivores: trophic cascades and top-down controls in coastal ecosystems past and present. In: Large Carnivores and the conservation of biodiversity (eds Ray, J., Redford, K., Steneck, R.S., Berger. J.), Island Press, Pp. 110-137.

Stimson, J., S. Larned and E. Conklin

2001. Effects of herbivory, nutrient levels, and introduced algae on the distribution and abundance of the invasive macroalga Dictyosphaeria cavernosa in Kaneohe Bay, Hawaii. Coral reefs 19 (4): 343-357.

Tourrand, C., O. Naim, L. Bigot, C. Cadet, B. Cauvin, S. Semple, L.F. Montaggioni, P. Chabanet and H. Bruggemann

2013. Fringing reefs of Reunion island and eutrophication effects. Part 1: Long-term monitoring of two shallow coral reef communities. Atoll Research Bulletin, 596: 33p.

Tsuda, R.T.

1974. Seasonal aspects of the Guan Phaeophyta (brown algae). Proceedings of the $2^{\text {nd }}$ International Coral reef Symposium, Great Barrier Reef, Australia 1: 43-47.

Vermeij, $\dagger$, M.J.A., M.L. Dailer, S.M. Walsh, M.K. Donovan and C.M. Smith

2010. The effects of trophic interactions and spatial competition on algal community composition on Hawaiian coral reefs. Marine Ecology 31 (2) : 291-299. 